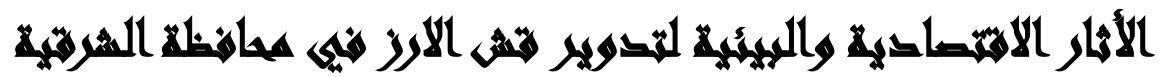

\section{[}

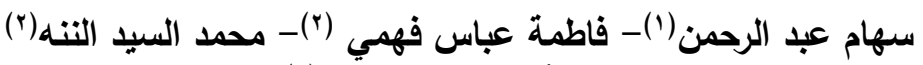

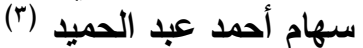

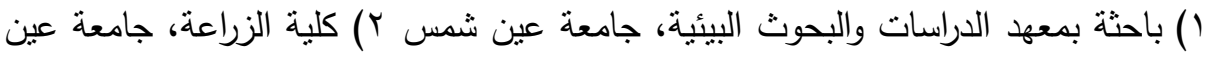

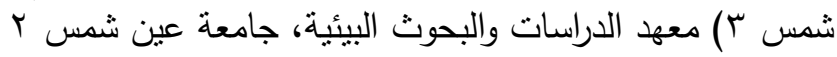

\section{المستخليه}

نظراً لمحدودية الإنتاج الزراعي والزيادة المسـتمرة لعدد سـكان مصـر ، فقد اتجهت الدولة العادئ

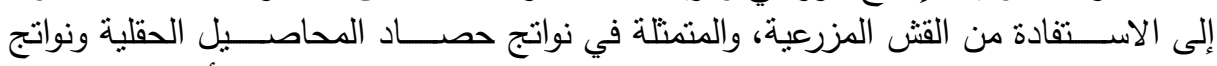

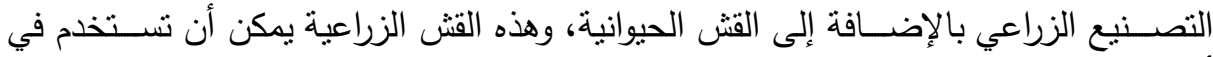

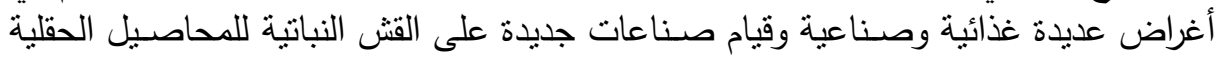

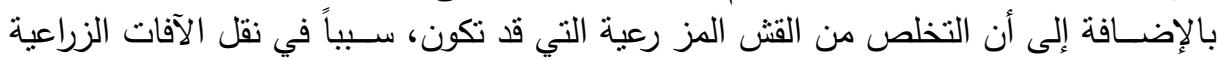

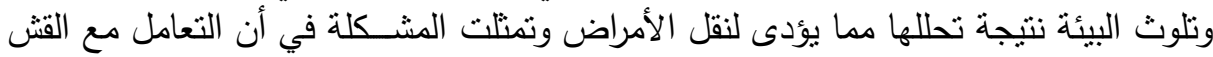

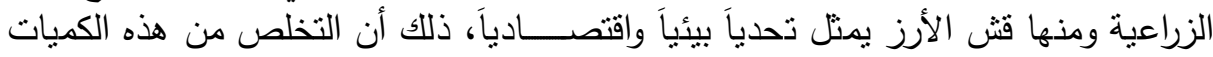

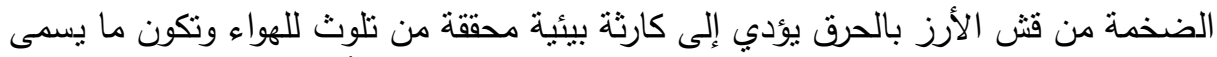

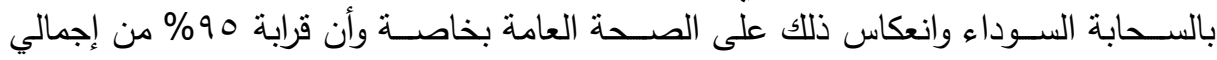

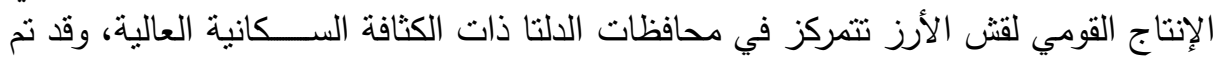

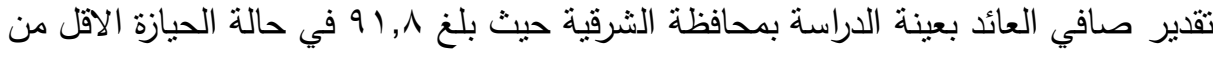

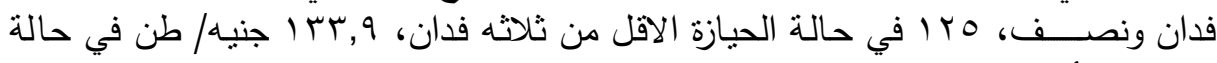

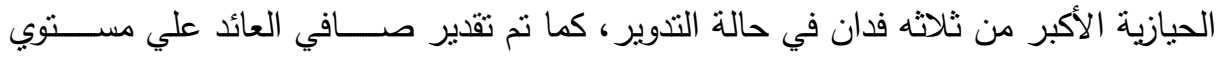

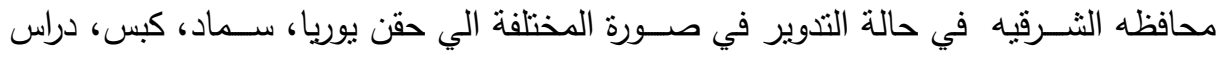

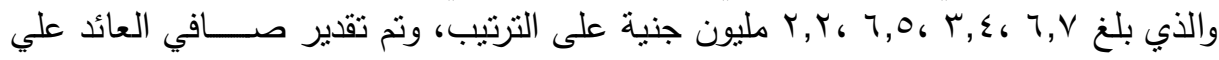

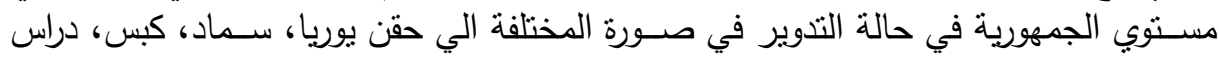

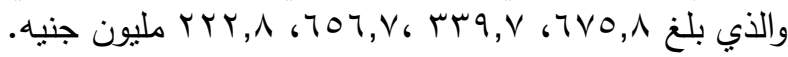

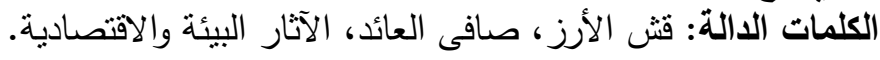




\section{xaradl}

نظراً لمحدودية الإنتاج الزراعي والزيادة المستمرة لعدد السكان في مصر، فقد اتجهت الدولة

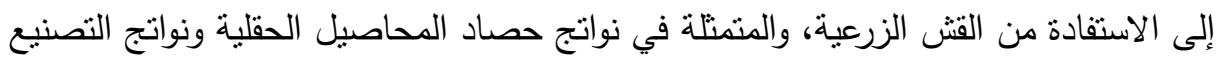
الزراعي بالإضافة إلى القش الحيوانية، وهذه القش الزراعية يمكن أن تستخدم في أغراض عدئ عديدة

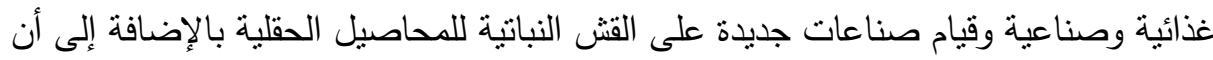
التخلص من القش المزرعية التي قد تكون سبياً في نقل الآفات الزراعية وتلوث البيئة نتيجة

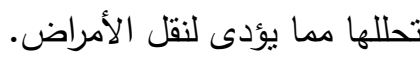

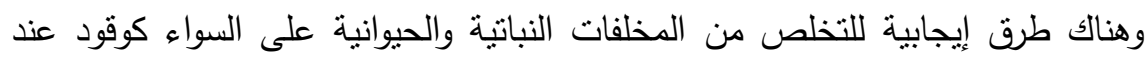
صناعة الخبز الفلاحى أو تدويرها واستخدامها في صناعة السماد العضوي والأعلاف الحيوانية

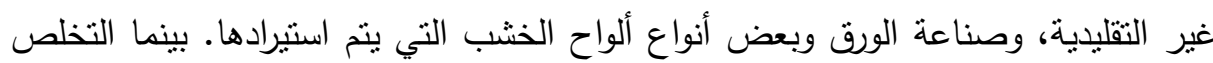

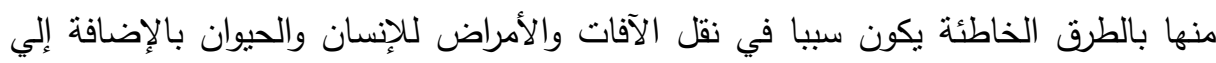

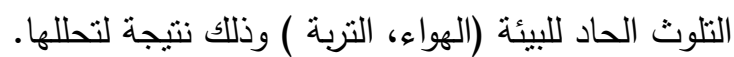
كما نستهدف العديد من السياسات الاقتصادية والزراعية التي تتبعها الدولة الي تحقيق التتمية الزراعية المستدامة وتوجيه كافة الجهود والإمكانيات نحو الاستفادة الكاملة من عناصر الإنتاج المحدودة في المجتمع. كما أن قيام صناعات جديدة على المخلفات الزراعية للمحاصيل الحقلية سوف تخلق دخولا

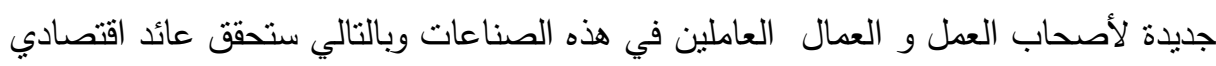
ملموس بجانب قيمة اقتصادية مضافة للإنتاج الزراعي، هذا بالإضافة إلي التخلص الآمن من لهن هذه المخلفات وبطريقة آمنه صحيا وبيئياً.

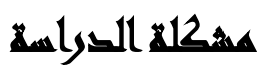

يعتبر محصول الأرز من المحاصيل ذات البعد الإستراتيجي في جمهورية مصر العربية نظراً لاعتماد الكثير من السكان عليه كغذاء رئيسي يحتوي على العديد من العناصر الغذائية

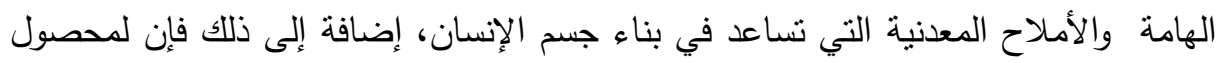
الأرز المصري أهية اقتصادية كبرى لما يتميز به من ميزات تتافسية في الأسواق المحلية 
والعالمية و لما له من خصائص شكلية و أكلية تتفق مع أذواق كثثر من المستهلكين، ولولا القيد

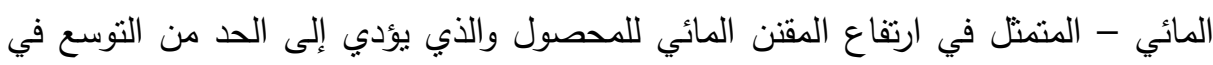
زراعته على المسنوى القومي - لكان محصول الأرز من أفضل الزراعات بالنسبة للمزارع المصري من حيث العائد الاقتصادي • وفي كل حالات الإنتاج سواء للتصدير للأسواق العالمية لإنية أو للاكتفاء الذاتي محلياً فإن ضخامة الإنتاج من محصول الأرز كمنتج رئيسي يقابله إنتاج

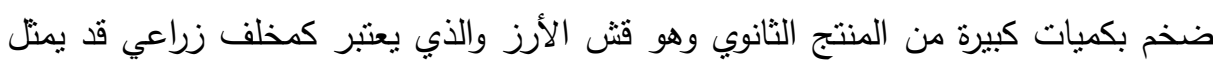
عبئًا بيئياً على حسب طريقة التخلص منه،، وعلى سبيل المثال فإذا علمنا أن إجمالي المساحة

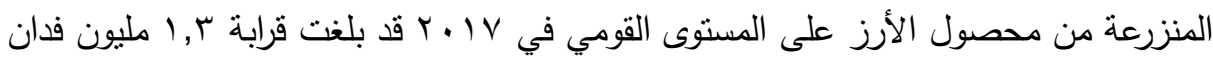
وكانت كمية الإنتاج تمنل حوالي ه مليون طن من الأرز فإن ذللك الإنتاج يقابله كمية من إنتاج

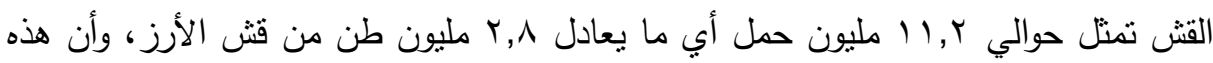
الكمية من القش مرهون تحقق الاستفادة منها أو الضرر البيئي على حسب البع التعامل معها.

\section{أهساهنم الصوراسلا}

1- دراسـة الأهمية النسـبية للمسـاحة المنزرعة وكمية الإنتاج وأسـعار قش الأرز كمنتج ثانوي لمحصول الأرز بمحافظة الثرقية مقارنة بمحافظات الجمهورية. r- دراسـة تطور كمية وإنتاجية وأسـعار ونسبة مسـاهمة قيمة المحصول الرئيسي والثانوي من

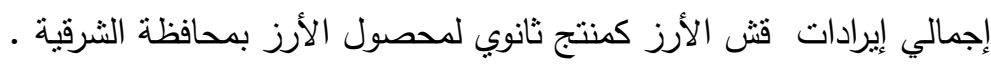

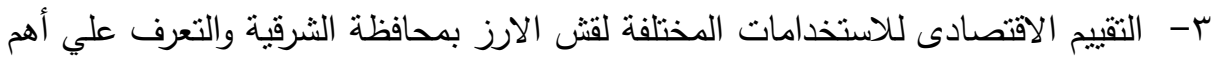

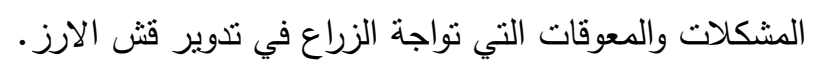

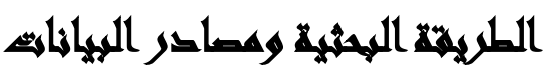

اعتمدت الدراسة على استخدام أسلوبي التحليل الوصفى والكمى الملائم لطبيعة الهدف من

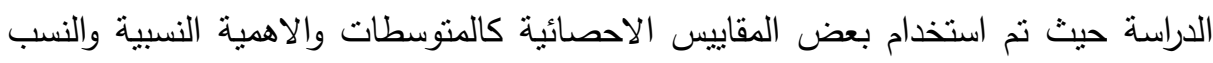

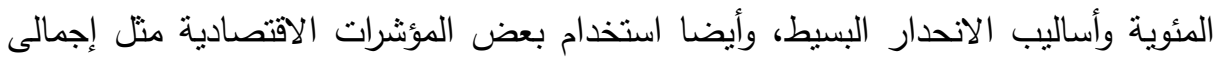

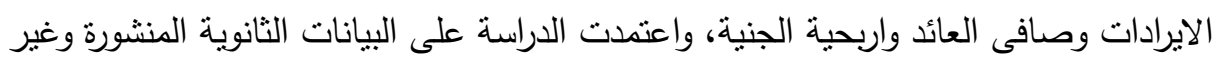

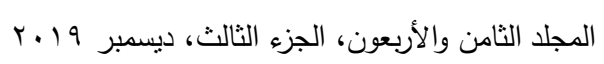


المنشورة من مصادرها المختلفة من الجهاز المركزى للتعبئة العامة والاحصاء، كما اعتمدت هذه

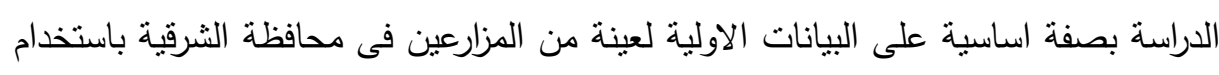

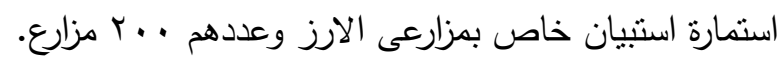

\section{نمائج الصواسم}

أولاً: المؤثــرات الإنتاجية لمحصــول الأرز في مصـر خلال الفترة (ه . . ب ـ

$(r \cdot 1 \mathrm{~V}$

1- المساحة المنزرعة: تشير بيانات جدول (1) إلى أن المساحة المنزرعة بمحصول الأرز

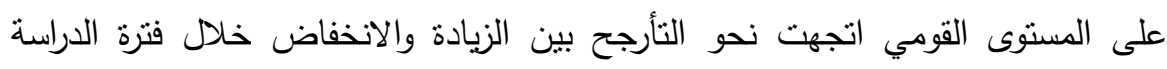

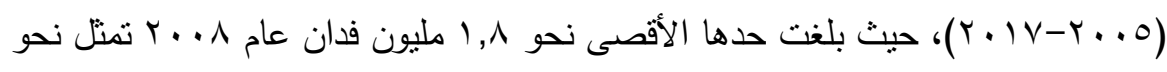

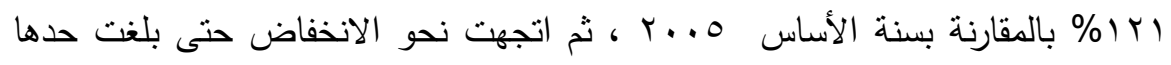

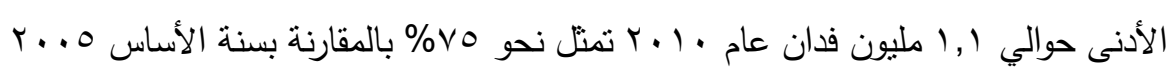

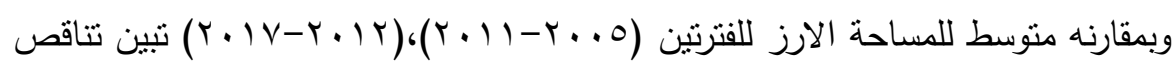

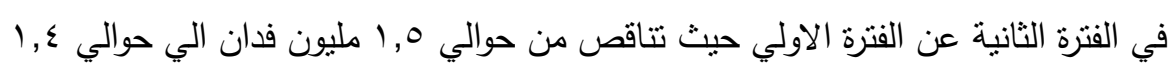
مليون فدان لكل من الفترتين علي التوالي، وقد بلغت منتوسط المساحة المنزرعة خلال فنرة

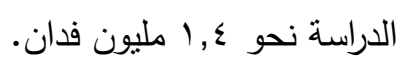

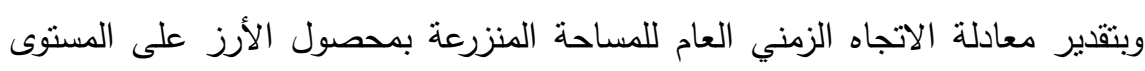

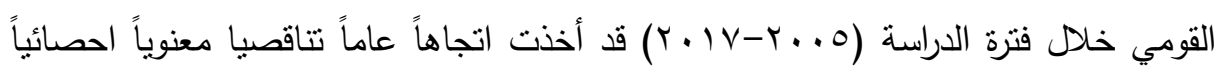

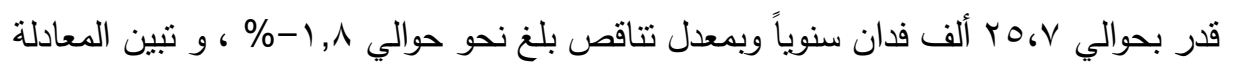

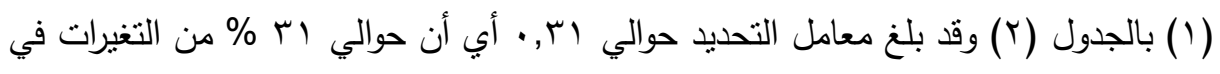

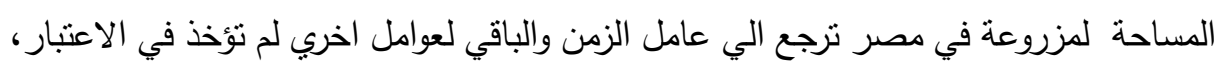

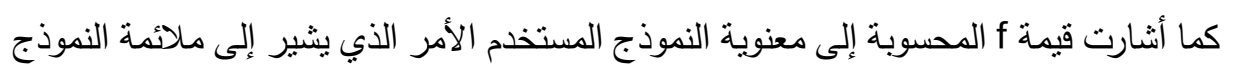
للبيانات موضع الدراسة. 
جلول (1): المؤشرات الإنتاجية لنطور محصول الأرز بجمهورية مصر العربية خلا الفترة

\begin{tabular}{|c|c|c|c|c|c|c|}
\hline & & & & \multicolumn{3}{|c|}{$(r \cdot I V-r \ldots 0)$} \\
\hline الرقم القياسي & مليون طن & الرقم القياسي & طن/فدانية & | الرقم القياسي & مليون فدانة & 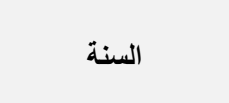 \\
\hline 100 & 6.1 & 100 & 4.20 & 100 & 1.5 & 2005 \\
\hline 110 & 6.7 & 101 & 4.23 & 109 & 1.6 & 2006 \\
\hline 112 & 6.9 & 98 & 4.11 & 115 & 1.7 & 2007 \\
\hline 118 & 7.2 & 97 & 4.09 & 121 & 1.8 & 2008 \\
\hline 90 & 5.5 & 96 & 4.03 & 94 & 1.4 & 2009 \\
\hline 71 & 4.3 & 94 & 3.96 & 75 & 1.1 & 2010 \\
\hline 93 & 5.7 & 96 & 4.02 & 97 & 1.4 & 2011 \\
\hline- & 6.1 & - & 4.1 & - & 1.5 & متوسط الفترة الاولي \\
\hline 96 & 5.9 & 95 & 4.01 & 101 & 1.5 & 2012 \\
\hline 93 & 5.7 & 96 & 4.03 & 97 & 1.4 & 2013 \\
\hline 89 & 5.5 & 95 & 4.00 & 93 & 1.4 & 2014 \\
\hline 79 & 4.8 & 94 & 3.96 & 83 & 1.2 & 2015 \\
\hline 87 & 5.3 & 93 & 3.92 & 93 & 1.4 & 2016 \\
\hline 81 & 5.0 & 90 & 3.79 & 90 & 1.3 & 2017 \\
\hline- & 5.5 & - & 4 & - & 1.4 & متوسط الفترة الثانية \\
\hline- & 5.7 & - & 4.03 & - & 1.4 & المتوسط العام \\
\hline- & 4.3 & - & 3.79 & - & 1.1 & الحد الادني \\
\hline- & 7.2 & - & 4.23 & - & 1.8 & الحد الاقصي \\
\hline
\end{tabular}

المصدر: جمعت وحسبت من بيانات وزارة الزراعة واستصلاح الأراضي، الإدارة المركزية للاقتصاد زراعي، نشرة الاقتصادالزراعي، أعداد متفرقة . 
جدول (Y): معادلات الاتجاه الزمني العام للمؤشرات الإنتاجية لنطور محصول الأرز بجمهورية

\begin{tabular}{|c|c|c|c|c|c|}
\hline & \multicolumn{5}{|c|}{ 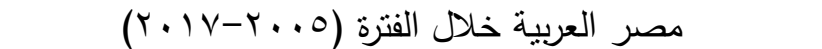 } \\
\hline معدل التغير من المتوسط \% & $\mathbf{F}$ & $\mathbf{R}^{2}$ & المعادلة المقدرة & المتغير & م \\
\hline$-1, \wedge$ & $\varepsilon, q$ & $\cdot, r$ & $\begin{array}{r}Y=1602.8-r_{\bullet}, v X \\
(i \vee, r) \quad(-2.3)^{*}\end{array}$ & | بالالف فدان الارز & 1 \\
\hline$-v$ & $r r, \Lambda$ & $\cdot, \wedge$. & $\begin{array}{l}Y=4.2-\cdot, \cdot r \mathrm{X} \\
(1 \mu r, \wedge) \quad(-6.7)^{* *}\end{array}$ & |لالاتناجية بالطن & $r$ \\
\hline$-r, 0$ & $\Lambda, r$ & r & $\begin{aligned} Y= & 6732.3-(\leqslant 1, \circ \mathrm{X} \\
& (1 \vee, r)(-2.9)^{*}\end{aligned}$ & | الانتاج بالالف & 3 \\
\hline
\end{tabular}

حيث : من : مساحة والانتاجية ، والانتاج

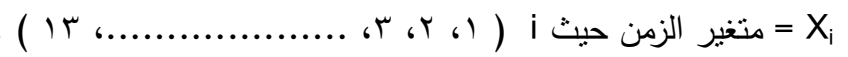

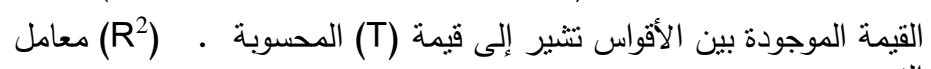

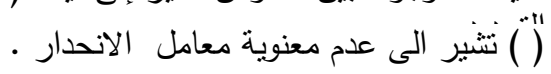

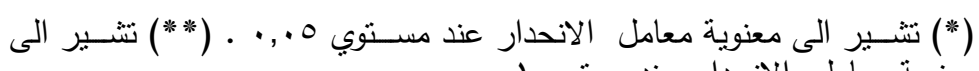

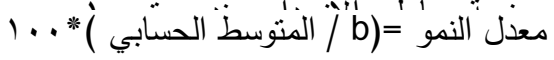

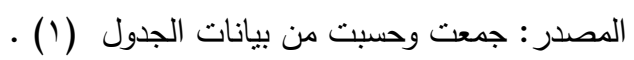

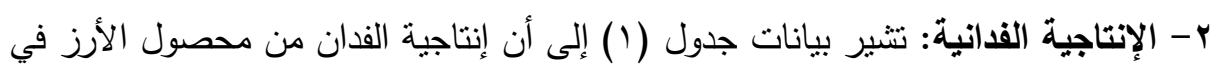

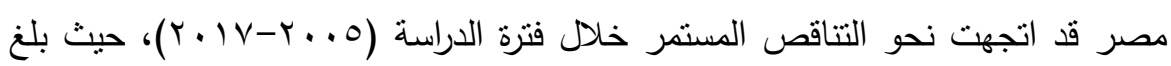

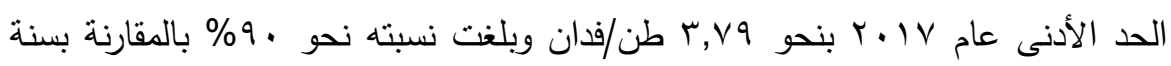

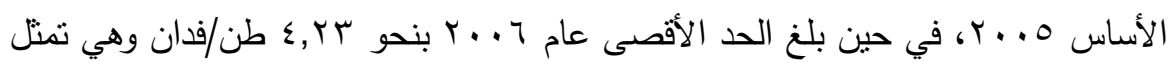

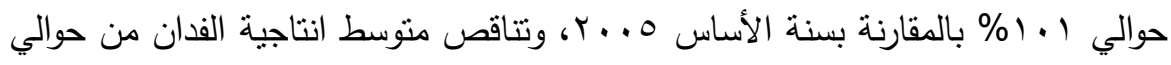

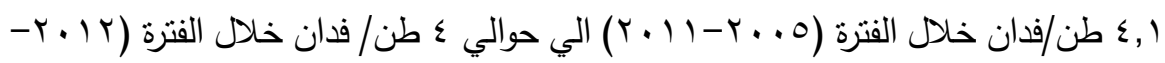

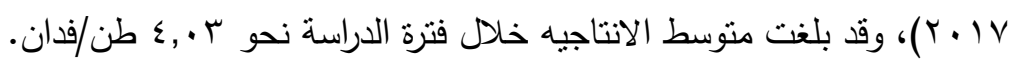
وتبين المعادلة (Y) بالجدول (Y) أنه بتقدير معادلة الاتجاه الزمني العام لإنتاجية الفدان

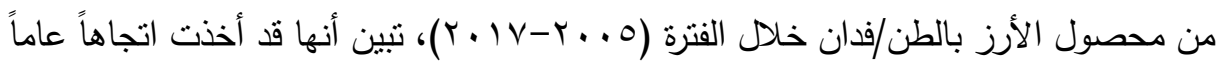

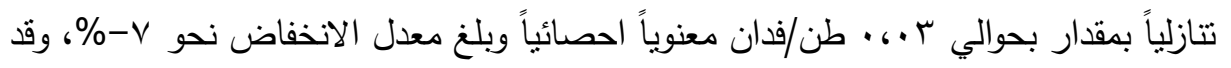

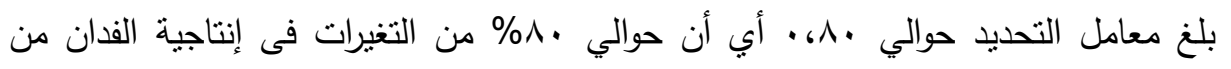


محصول الأرز في مصر ترجع لعامل الزمن والباقي لعوامل اخري لم تأخذ في الاعتبار، هذا

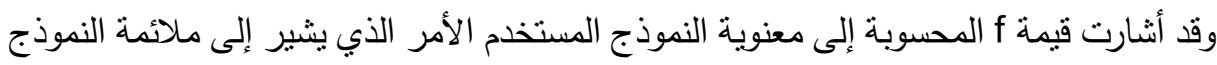
للبيانات موضع الدراسة. ب- كمية الإنتاج: تشير بيانات جدول ( ) إلى أن كمية الإنتاج لمحصول الأرز على المستوى

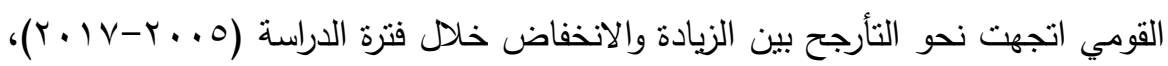

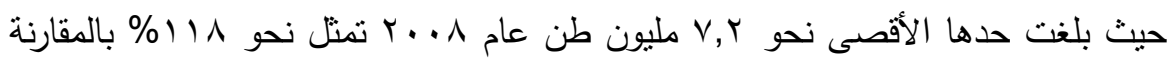

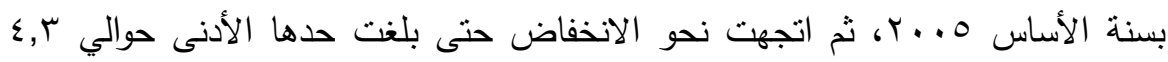

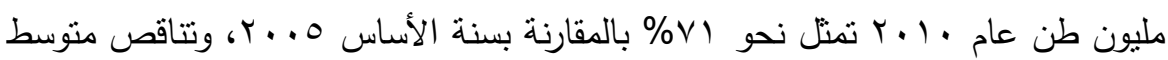

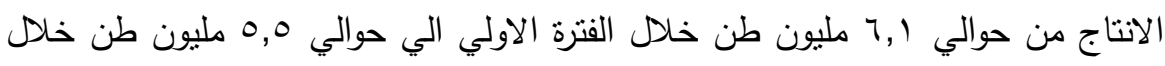
الفترة الثانية وهذا راجع الي تتاقص متوسط كلا من المساحة والانتاجية خلال تلك الفترنين،

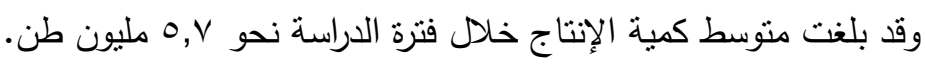

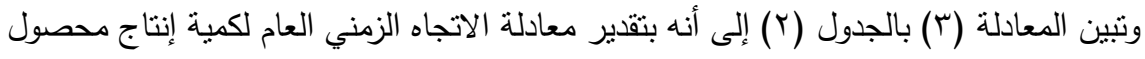

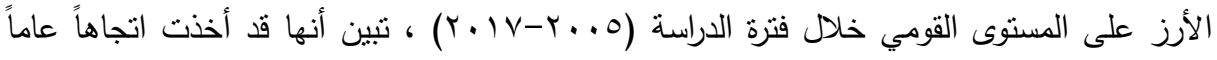

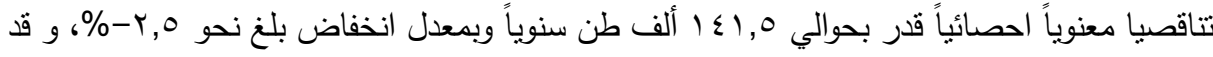

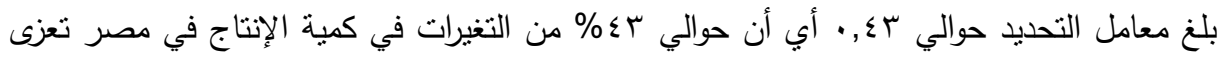

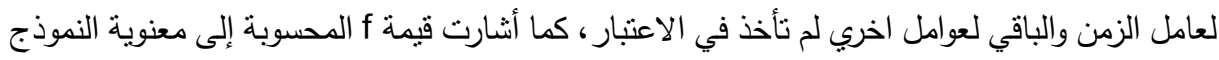

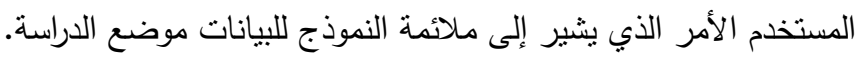
ثانياً: المؤشرات الإنتاجية والاقتصادية لتطور قش الأرز بجمهورية مصر الإية لإنية مرضية

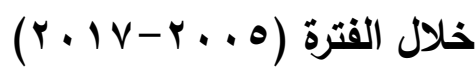

1-كمية الإنتاج من قش الأرز: تشير بيانات جدول (r) إلى أن كمية الإنتاج لقش الأرز

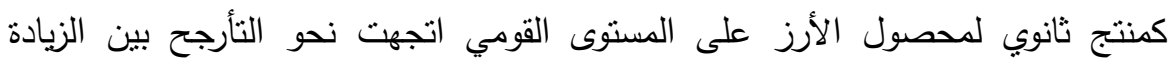

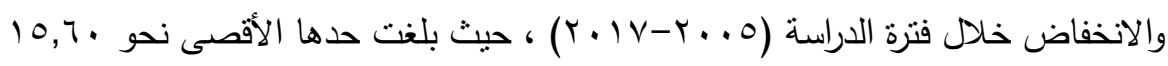

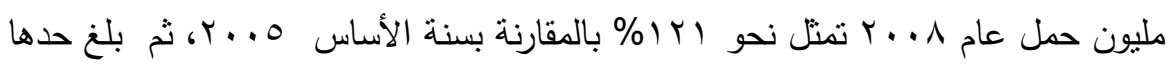

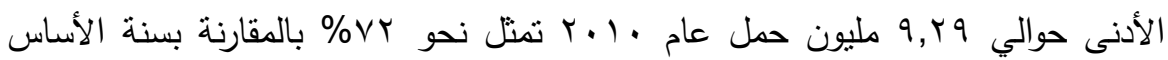




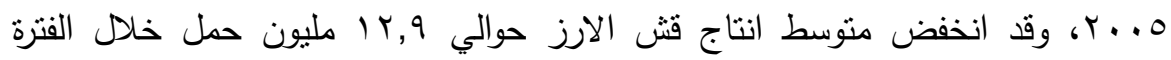

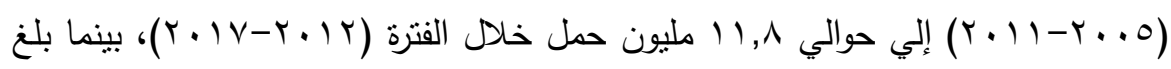

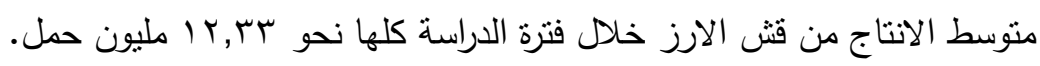

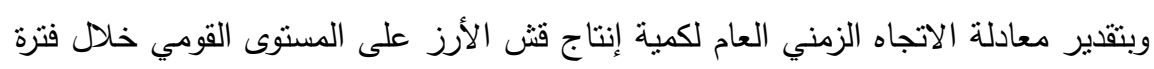

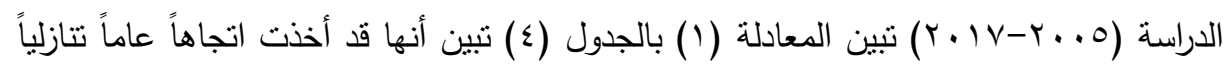

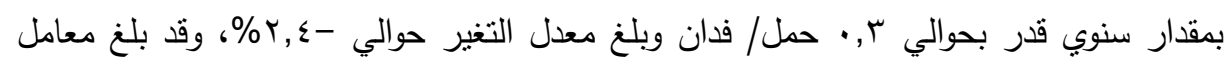

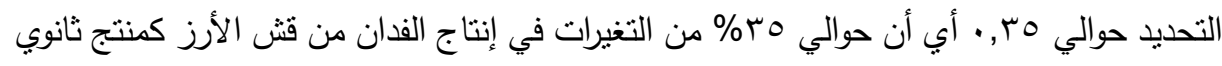

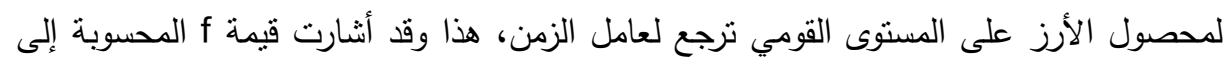

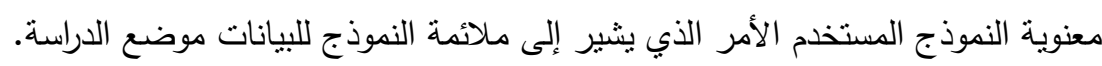

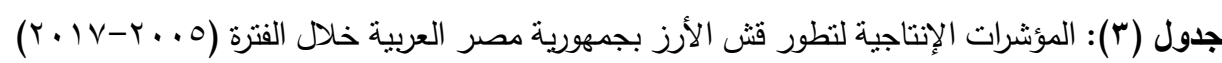

\begin{tabular}{|c|c|c|c|c|}
\hline القياسيقة & حمل / فالدانة & القياسيبة & كمية الإنتاج بالمليون حمل * & السنة \\
\hline 100 & 8.8 & 100 & 12.9 & 2005 \\
\hline 101 & 8.9 & 111 & 14.2 & 2006 \\
\hline 102 & 8.9 & 116 & 14.9 & 2007 \\
\hline 100 & 8.8 & 121 & 15.6 & 2008 \\
\hline 96 & 8.5 & 90 & 11.6 & 2009 \\
\hline 96 & 8.5 & 72 & 9.3 & 2010 \\
\hline 97 & 8.5 & 93 & 12.0 & 2011 \\
\hline- & 8.7 & - & 12.9 & المتوسط الفترة الاولي \\
\hline 97 & 8.6 & 98 & 12.6 & 2012 \\
\hline 97 & 8.6 & 94 & 12.2 & 2013 \\
\hline 97 & 8.6 & 91 & 11.7 & 2014 \\
\hline 97 & 8.6 & 81 & 10.4 & 2015 \\
\hline 97 & 8.6 & 90 & 11.6 & 2016 \\
\hline 97 & 8.5 & 87 & 11.2 & 2017 \\
\hline- & 8.6 & - & 11.8 & المتوسط الفترة الثانية \\
\hline- & 8.7 & - & 12.3 & المتوسط الفترة الاولي \\
\hline- & 8.5 & - & 9.3 & الحد الادني \\
\hline- & 8.9 & - & & الحد الاقصي \\
\hline
\end{tabular}

المصدر: جمعت وحسبت من: بيانات وزارة الزراعة واستصلاح الأراضي، الإدارة المركزية للاقتصاد

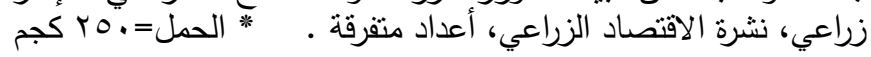


جدول (§): معادلات الاتجاه الزمني العام للمؤشرات الإنتاجية لتطور قش الأرز بجمهورية

\begin{tabular}{|c|c|c|c|c|c|}
\hline معدل التغير من & $\mathrm{F}$ & $\mathrm{R}^{2}$ & المعادلة المقدرة & المتغير & s \\
\hline$-\Upsilon, \xi$ & 0,9 & - ro & $\begin{array}{c}\mathrm{Y}=14.2-,, r \mathrm{X} \\
(1 \nsucc, r)(- \\
2.4)^{*}\end{array}$ & بالمليون ممل الانتاج & 1 \\
\hline$-\cdot, r$ & $1 \cdot, \wedge$ & $\cdot, 0$ & $\begin{array}{c}\mathrm{Y}=8.9-\cdot, \cdot r \mathrm{X} \\
\quad(1 r Y, \cdot 1) \quad(- \\
3.3)^{*}\end{array}$ & فدان الإنتاجية ممل / & $r$ \\
\hline
\end{tabular}

$$
\text { حيث : Y = كمية الانتاج ، الانتاجيه. }
$$

o $=X_{i}$

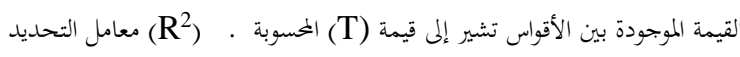

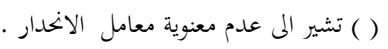

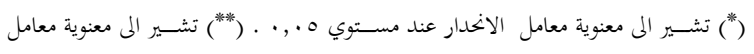

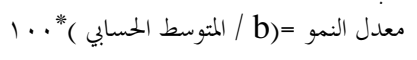

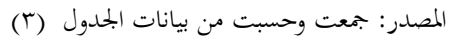

r- الإنتاجية الفدانية: تشير بيانات جدول (r) إلى أن إنتاجية الفدان من قش الأرز كمنتج

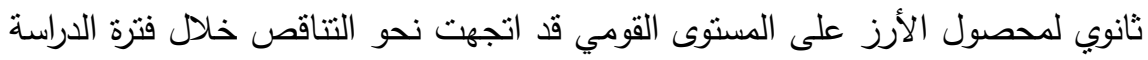

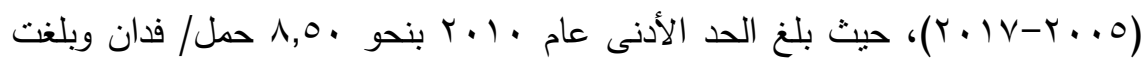

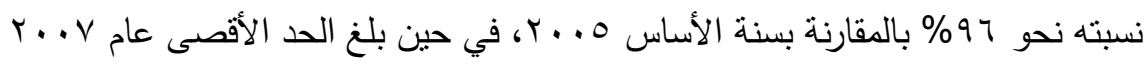

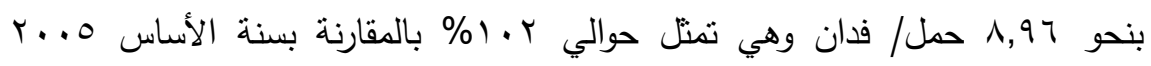

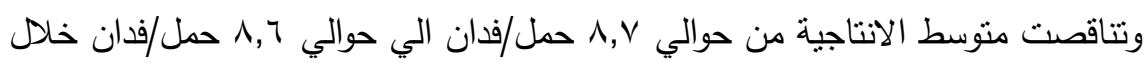

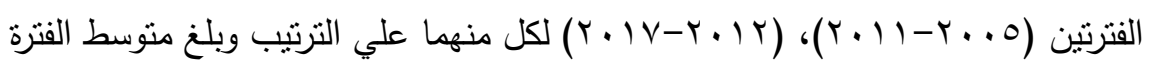
كلها حوالي 1,07 حمل /فدان. 
وتبين المعادلة (r) بالجدول (ع) أنه بتقدير معادلة الاتجاه الزمني العام لإنتاجية الفدان

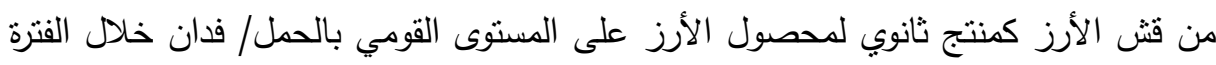

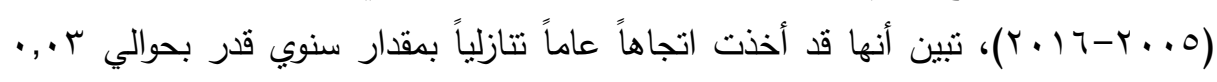

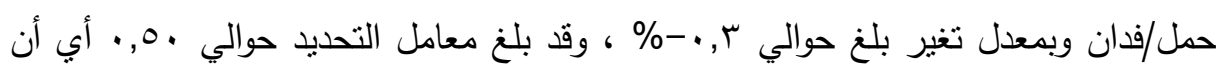

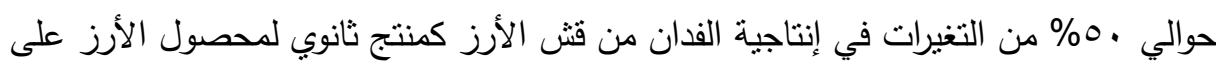

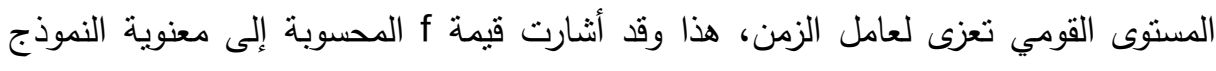

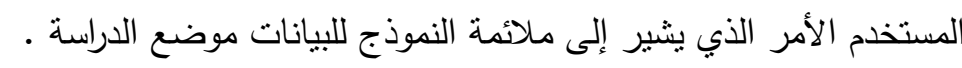
ثالثا:الأهمية النسبية للطاقة الإنتاجية لمحصول الأرز أهم في محافظات مصر

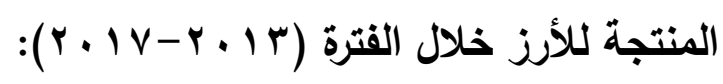

1-الأهمية النسبية للمساحة المزروعة من الارز في أهم المحافظات: باستعراض بيانات

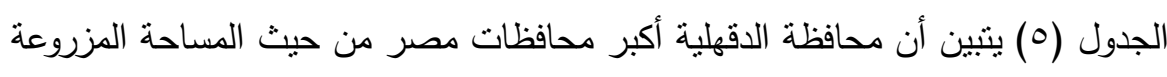
خلال فترة الدراسة حيث تساهم بنحو r, •r\% من أجمالي المساحة المزروعة، ثم تأنى أنى

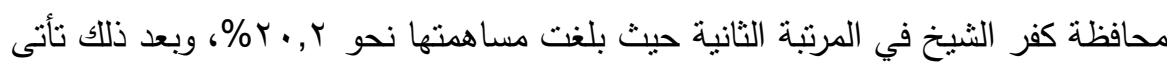

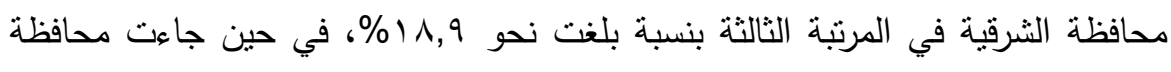

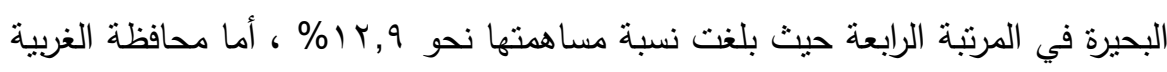
فجاءت في المرتبة الخامسة بنسبة بلغت نحو ^, 9\%، ثم جاءت محافظه دمياط في المرتبة السادسة بنسه بلغت 7 ؛ \% . مما سبق ينتين أن محافظات الدقهلية وكفر الثيخ والثرقية بيتركز بها نحو ع,97\% من إجمالي مساحة الارز في مصر . 
جدول رقم (•): المساحة المزروعة من الارز بالألف فدان لأهم محافظات مصر وأهميتها

(الوحدة : ألف فدان)

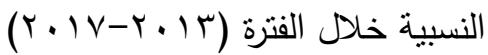

\begin{tabular}{|c|c|c|c|c|c|c|c|c|}
\hline الترتيب & $\%$ & المتوسط & $r+1 V$ & $r .17$ & $r+10$ & $r+1 \varepsilon$ & $r \cdot 1 r$ & المحافظات \\
\hline 1 & 30.3 & 403.8 & 391.9 & 414.4 & 380.7 & 408.9 & 422.7 & الدقهليـة \\
\hline 2 & 20.2 & 269.4 & 258.3 & 271.7 & 248.9 & 276.1 & 291.9 & كفر الثيخ \\
\hline 3 & 18.9 & 251.2 & 276.7 & 266.6 & 221.1 & 244.9 & 246.8 & الثـرقية \\
\hline 4 & 12.9 & 171.7 & 164.1 & 166.3 & 162.5 & 176.7 & 188.8 & البحــيرة \\
\hline 5 & 9.8 & 130.8 & 119.6 & 127.9 & 108.5 & 144.5 & 153.5 & الغربيــة \\
\hline 6 & 4.6 & 61.6 & 57.0 & 61.4 & 58.7 & 64.1 & 67.1 & دميــاط \\
\hline \multirow[t]{2}{*}{7} & 3.3 & 43.3 & 39.3 & 44.9 & 35.3 & 48.6 & 48.6 & اخري \\
\hline & 100.00 & 1331.9 & 1307.1 & 1353.3 & 1215.8 & 1363.8 & 1419.4 & اجمالي الجمهورية \\
\hline
\end{tabular}

المصدر: جمعت وحسبت من بيانات وزارة الزراعة واستصلاح الاراضي، قطاع الثؤن الاقتصادية، نشرة

الإحصاءات الزراعية، اعداد مختلفة.

r- الأهمية النســبية للإنتاجية الفدانية لمحصــول الارز في أهم المحافظات: باســتعراض الاض

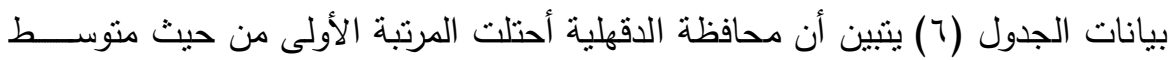

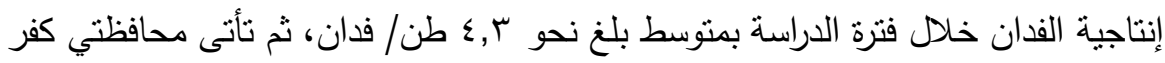

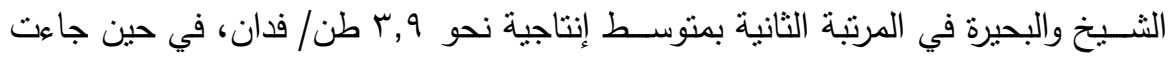

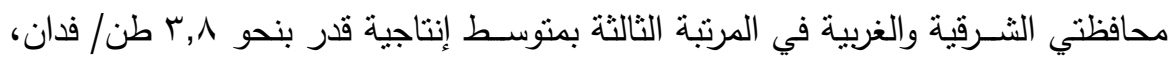

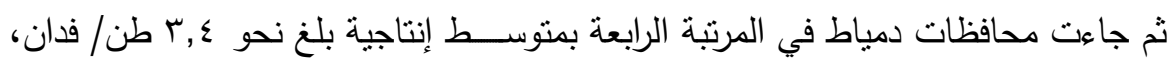

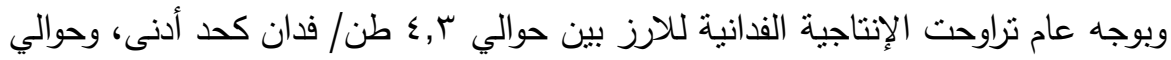
^r, ب طن/ فدان كحد أعلى كمتوسط لتلك الفترة. 
جدول رقم (؟): لإنتاجية الفدانية من الارز في أهم محافظات مصر المنتجة للأرز أهميتها

\begin{tabular}{|c|c|c|c|c|c|c|c|}
\hline \multicolumn{3}{|c|}{ ( الوحدة : طن/ فدان) } & \multicolumn{4}{|c|}{ 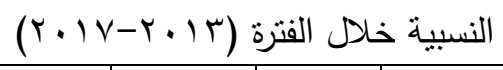 } & \\
\hline الترتيب & المتوسط & $r .1 V$ & $r .17$ & $r .10$ & $r .1 \varepsilon$ & $r .1 r$ & ل لمحافظات \\
\hline 1 & 4.3 & 4.2 & 4.2 & 4.4 & 4.3 & 4.3 & الدقهليــة \\
\hline 2 & 3.9 & 3.9 & 3.9 & 3.8 & 3.9 & 3.9 & كفر الشيخ \\
\hline 2 & 3.9 & 3.8 & 3.8 & 3.8 & 4.0 & 4.0 & البحـيرة \\
\hline 3 & 3.8 & 3.3 & 3.9 & 3.9 & 3.8 & 3.9 & الثرقية المقية \\
\hline 3 & 3.8 & 3.8 & 3.6 & 3.5 & 3.9 & 4.0 & الغربيــة \\
\hline 4 & 3.4 & 3.4 & 3.4 & 3.1 & 3.4 & 3.6 & دميـاط \\
\hline & 3.9 & 3.8 & 3.9 & 4.0 & 3.9 & 4.0 & إجمالي الجمهورية \\
\hline
\end{tabular}

المصدر: جمعت وحسبت من بيانات وزارة الزراعة واستصلاح الاراضي، قطاع الثشؤن الاقتصادية، نشرة

الإحصاءات الزراعية، اعداد مختلفة.

r- الأهمية النسبية للإنتاج الكلي من محصول الارز في أهم المحافظات : باستعراض بيانات الجدول رقم (V) والذي يبين المتوسط والاهمية النسبية للمحافظات المنتجة للارز ، يتضح

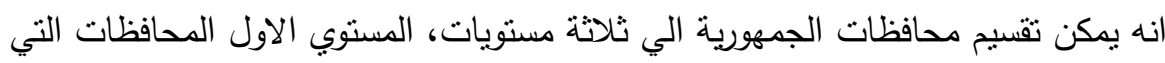
تساهم بما يزيد عن 10\% من الانتاج المصري من الارز وتضم محافظات الدقهلية بنسبه

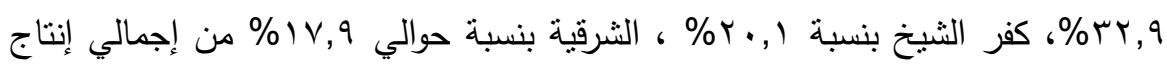

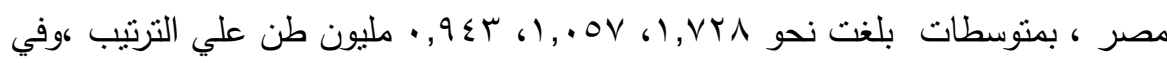
المرتبة الثانية المحافظات التي تتتج اقل من 10 \% من الانتاج المصري من الارز وتضم

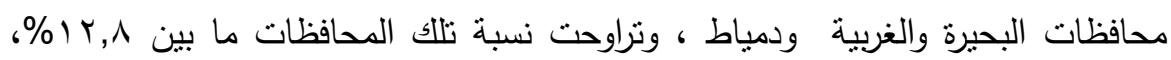

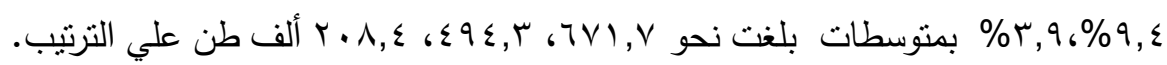


جلول رقم (V): الإنتاج الكلي من الارز بالألف طن في محافظات مصر وأهميتها النسبية

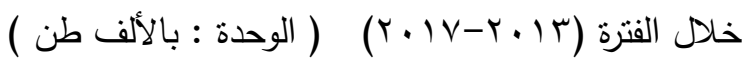

\begin{tabular}{|c|c|c|c|c|c|c|c|c|}
\hline الترتيب & $\%$ & المتوسط & r. IV & r.17 & $r .10$ & $r .1 \varepsilon$ & $r .1 r$ & المحافظات \\
\hline 1 & 32.9 & 1728 & 1631.3 & 1733.7 & 1686.3 & 1771.1 & 1817.7 & الدقطليــة \\
\hline 2 & 20.1 & 1056.8 & 1026.4 & 1069.7 & 953.7 & 1088.6 & 1145.6 & كفر الثيخ \\
\hline 3 & 17.9 & 943 & 902.7 & 1051.1 & 869 & 931.9 & 962.8 & الشرقية \\
\hline 4 & 12.8 & 671.7 & 625.9 & 629.4 & 622.6 & 715.5 & 765.1 & البحـيرة \\
\hline 5 & 9.4 & 494.3 & 451.9 & 461.4 & 378.7 & 563.4 & 616.3 & الغرييـة \\
\hline \multirow[t]{3}{*}{6} & 3.9 & 208.4 & 194.5 & 206.5 & 181.4 & 221.3 & 238.4 & دميـاط \\
\hline & 2.9 & 149.5 & 124.6 & 156.3 & 126.3 & 168.9 & 171.2 & اخري \\
\hline & 100.00 & 5252.3 & 4957.5 & 5308.2 & 4817.9 & 5460.8 & 5717.1 & إجمالي \\
\hline
\end{tabular}

المصدر: جمعت وحسبت من بيانات وزارة الزراعة واستصلاح الاراضي، قطاع الثؤن الاقتصادية، نشرة الإحصاءات الزراعية، اعداد مختلفة. الأهمية النسبية للطاقة الإنتاجية والسعر للقش من محصول الارز في أهم محافظات مصر

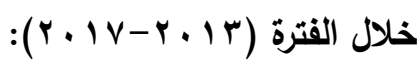
1-الأهمية النسبية لسعر الحمل من قش الارز في أهم المحافظات : باستعراض بيانات الجدول (^) يتبين أن محافظة الثرقية أكبر محافظات مصر من حيث سعر الحمل خلال فترة الدراسة حيث بلغ متوسط السعر حوالي رب جنية للحمل، ثم تأنى محافظة دمياط في المرنبة الثانية حيث بلغ متوسط السعر حوالي هب جنية للحمل، وبعد ذلك تأتى محافظتي كفر الثيخ والبحيرة في المرتبة الثالثة حيث بلغ منوسط السعر حوالي ؟ب جنية للحمل، في حين جاءت محافظة الغربية في المرتبة الرابعة حيث بلغ متوسط السعر حوالي بr جنية للحمل، أما محافظة الدقهلية فجاءت في المرتبة الخامسة حيث بلغ متوسط السعر حوالي بr جنية. 
جدول رقم (^): سعر الحمل من فش الارز لأهم محافظات مصر وأهميتها النسبية خلال الفترة

\begin{tabular}{|c|c|c|c|c|c|c|c|}
\hline \multicolumn{5}{|c|}{ ( الوحدة : جنية للحمل) } & \multicolumn{3}{|c|}{$(r \cdot I V-r \cdot 1 r)$} \\
\hline الترتيب & المتوسط & 2017 & 2016 & 2015 & 2014 & 2013 & المحافظات \\
\hline 1 & 38 & 38 & 38 & 38 & 38 & 38 & الثشرقية \\
\hline 2 & 35 & 35 & 35 & 35 & 35 & 33 & دميــاط \\
\hline 3 & 34 & 36 & 35 & 34 & 33 & 32 & البحـيرة \\
\hline 3 & 34 & 34 & 34 & 34 & 34 & 32 & كفر الثـيخ \\
\hline 4 & 33 & 33 & 33 & 33 & 33 & 33 & الغربيــة \\
\hline 5 & 32 & 32 & 32 & 32 & 31 & 31 & الدقهيــة \\
\hline & 34 & 34 & 34 & 34 & 34 & 33 & الجمهورية \\
\hline
\end{tabular}

المصدر : جمعت وحسبت من بيانات وزارة الزراعة واستصلاح الاراضي، قطاع الثؤن الاقتصادية، نشرة الاسعار الزاعية الزراعية اعداد مختلفة.

r- الأهمية النسـبية للإنتاجية الفدانية لقش محصــول الارز في أهم المحافظات المنتجة

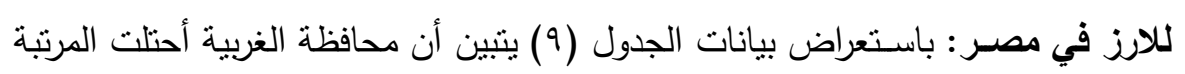

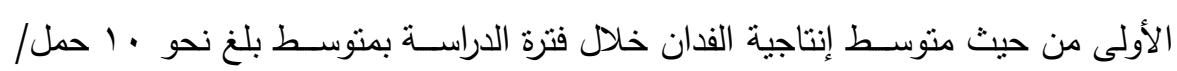

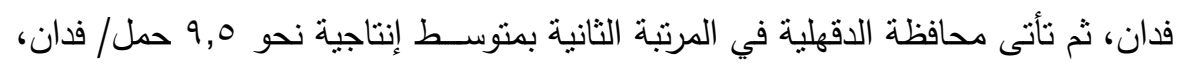

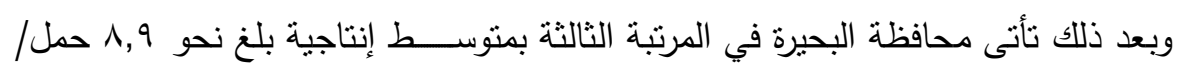

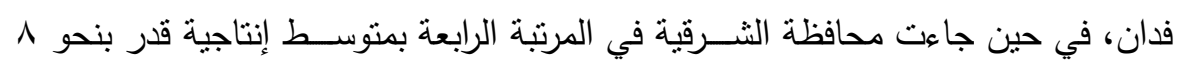

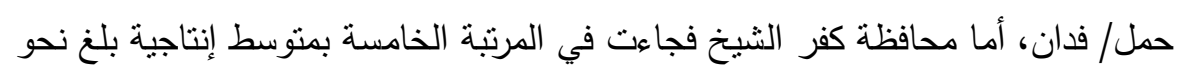

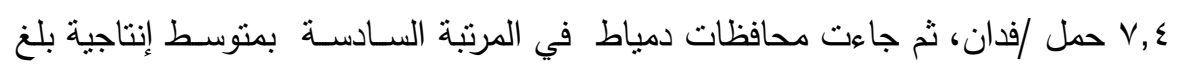

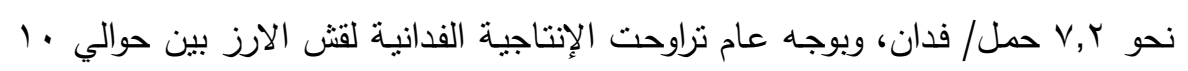

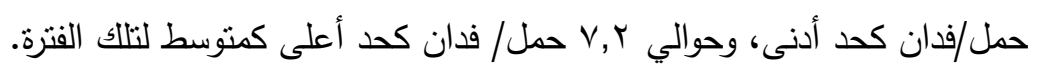


جدول رقم (9): الإنتاجية الفدانية من قش الارز في أهم محافظات مصر المنتجة للارز

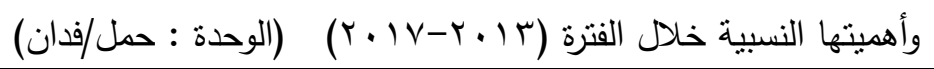

\begin{tabular}{|c|c|c|c|c|c|c|c|}
\hline الترتيب & المتوسط & 2017 & 2016 & 2015 & 2014 & 2013 & المحافظات \\
\hline 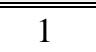 & 10.0 & $\begin{array}{l}10.0 \\
\end{array}$ & $\begin{array}{l}10.0 \\
\end{array}$ & $\begin{array}{l}10.0 \\
\end{array}$ & $\begin{array}{l}10.0 \\
\end{array}$ & $\bar{~} 10.0$ & الغربـــة \\
\hline 2 & 9.5 & 9.5 & 9.5 & 9.5 & 9.5 & 9.5 & الدقطعــــة \\
\hline 3 & 8.9 & 8.9 & 8.9 & 8.9 & 8.9 & 8.9 & البح برة \\
\hline 4 & 8.0 & 8.0 & 8.0 & 8.0 & 8.0 & 8.0 & الثــرقبة \\
\hline 5 & 7.4 & 7.5 & 7.5 & 7.4 & 7.4 & 7.3 & لر الثـبـخ \\
\hline 6 & 7.2 & 7.2 & 7.2 & 7.2 & 7.2 & 7.1 & دمبــاط \\
\hline & 8.6 & 8.6 & 8.6 & 8.6 & 8.6 & 8.6 & الجمهوربة \\
\hline
\end{tabular}

المصدر: جمعت وحسبت من بيانات وزارة الزراعة واستصلاح الاراضي، قطاع الثؤن الاقتصادية، نشرة الاسعار الزاعية الزراعية اعداد مختلفة.

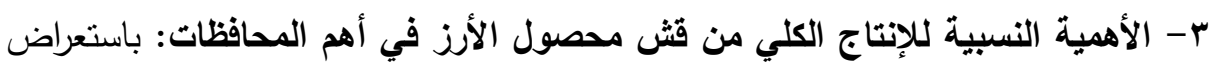
بيانات الجدول رقم (·) والذي يبين المتوسط والاهمية النسبية للمحافظات المنتجة لمخلفات الارز، يتضح انه يمكن تقسيم محافظات الجمهورية الي ثلاثة مستويات، المستوي الاول المحافظات التي التي تساهم بما يزيد عن 10\% من لهن الانتاج المصري من فث الارز

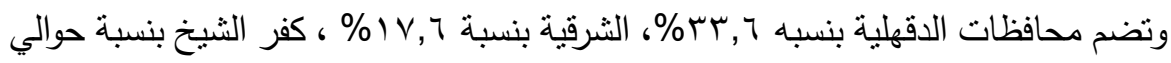

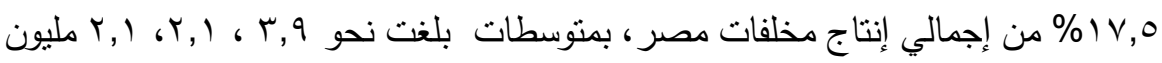
حمل علي الترتيب، وفي المرتبة الثانية المحافظات التي تتتج اقل من 10 \% من الانتاج

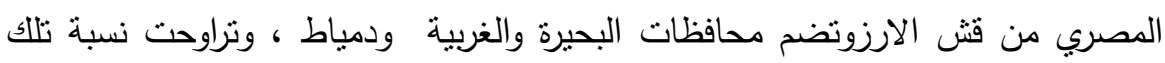

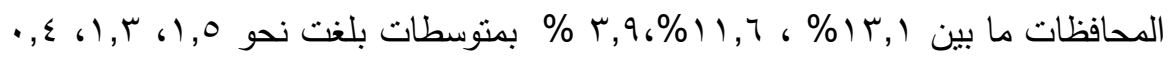
مليون حمل علي الترتيب وقد يشير ذلك إلى مدى التأثثر النسبي لمحافظة الثرقية في

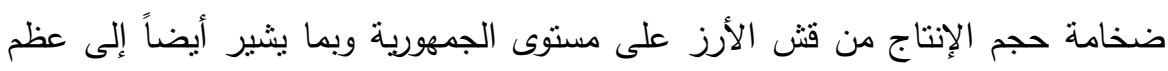

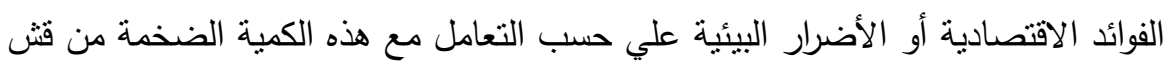

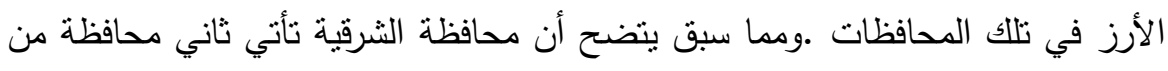

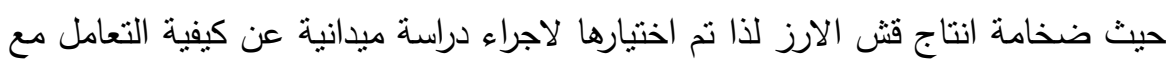


جدول رقم (• (): الإنتاج الكلي من فش الارز بالألف طن في محافظات مصر وأهميتها النسبية

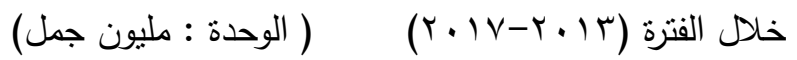

\begin{tabular}{|c|c|c|c|c|c|c|c|c|}
\hline الترتيب & $\%$ & المتوسط & 2017 & 2016 & 2015 & 2014 & 2013 & المحافظات \\
\hline 1 & 33.6 & 3.9 & 4.3 & 3.9 & 3.6 & 3.9 & 4.0 & الدقهليـــة \\
\hline 2 & 17.6 & 2.1 & 2.5 & 2.1 & 1.8 & 1.9 & 1.9 & الثـرقية \\
\hline 3 & 17.5 & 2.1 & 2.2 & 2.0 & 1.9 & 2.0 & 2.1 & كفر الثــيخ \\
\hline 4 & 13.1 & 1.5 & 1.5 & 1.5 & 1.4 & 1.6 & 1.7 & البحــــرة \\
\hline 5 & 11.6 & 1.4 & 1.5 & 1.3 & 1.1 & 1.4 & 1.5 & الغربيـــة \\
\hline \multirow[t]{3}{*}{6} & 3.9 & 0.4 & 0.5 & 0.4 & 0.4 & 0.5 & 0.5 & دميــاط \\
\hline & 2.7 & 0.3 & 0.4 & 0.3 & 0.2 & 0.3 & 0.3 & اخري \\
\hline & 100 & 11.7 & 12.8 & 11.6 & 10.4 & 11.7 & 12.2 & الجمهورية \\
\hline
\end{tabular}

عينة الاراسة:

يزرع محصـول الأرز كحصـول صيفى بمراكز وقرى محافظة الثـرقية، وقد تم استخدام

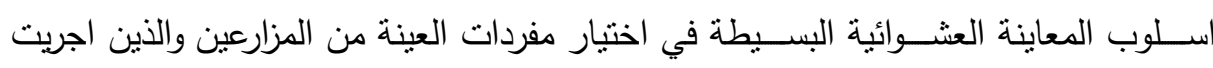
عليهم الدراسة مع مراعاه أن تعكس فئات حيازية مختلفة، وذللك بالرجوع الى كثوف الجئية الجمعيات.

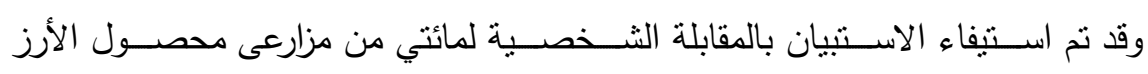

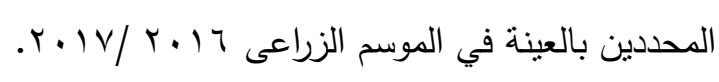

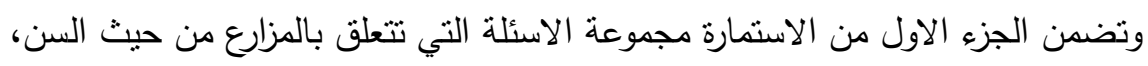

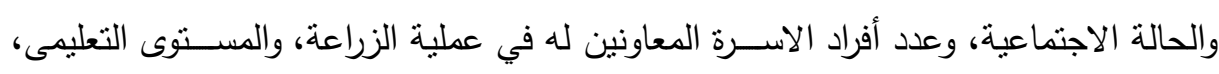

وكذلك اذا كان يمتهن مهنة اخرى بجوار عملية الزراعة، وكذلك الحيازة.

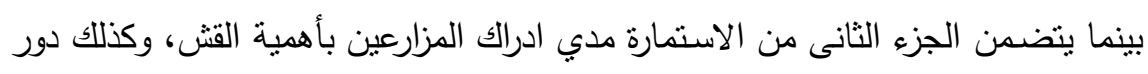

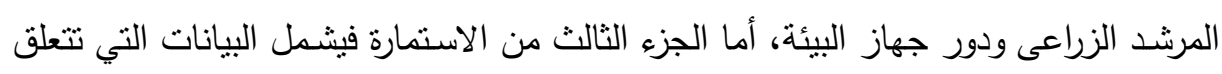

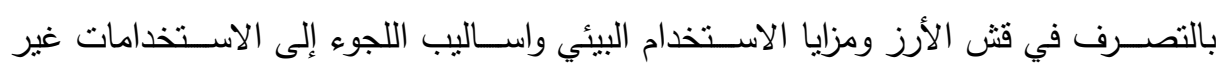

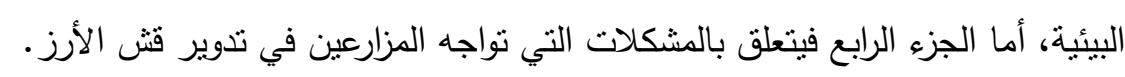

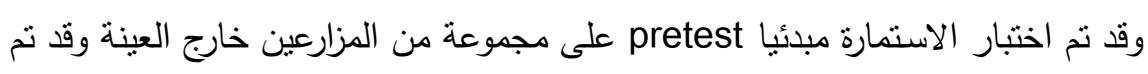
اجراء التعديلات المطلوبة قبل التجميع ومن ثم تم التجميع والمراجعة لضمان استيفاء البيانات، 
ثم تفريغ كل اسـتمارة على حدة ، وبالتالى تم تحليل البيانات المتحصـل عليها حيث توصـلت

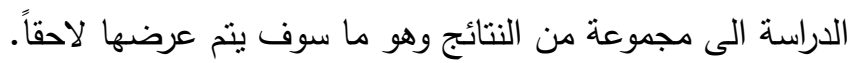

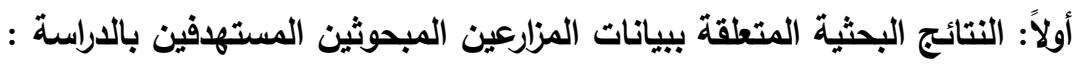

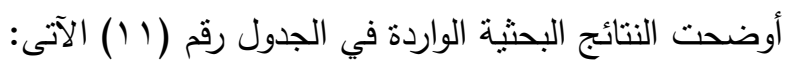

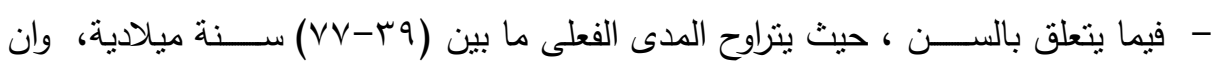

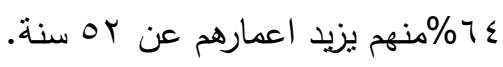

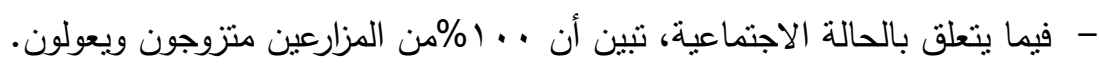

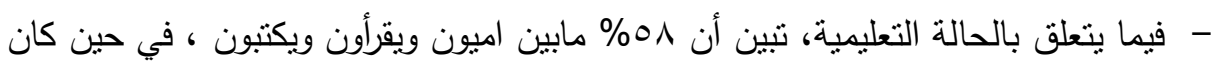

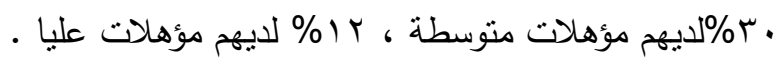

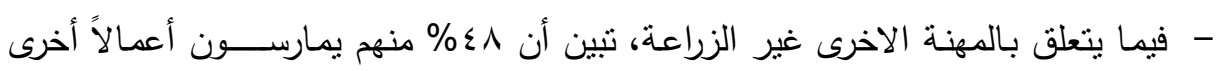

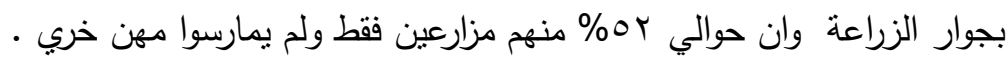

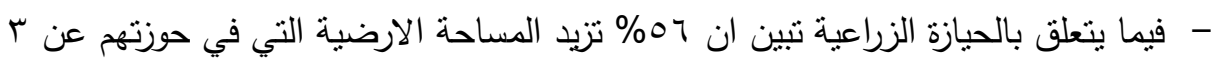

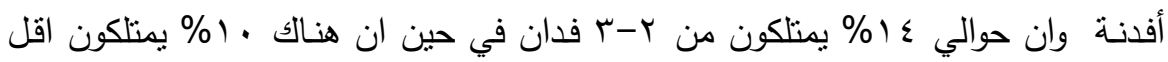

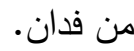
مما سبق يتبين أن أكثر من •0\% من افراد العينة تجاوزوا سن الخمسين ، حوالي بr\%

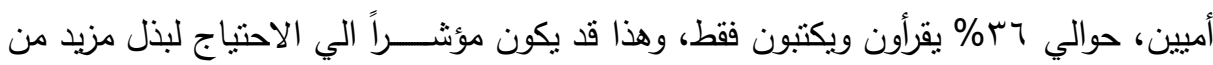
الجهد لتغيير عاداتهم في كيفية التخلص من قش الارز بطريقة غير امنه (بطريقة تقليديـة) واقتاعهم للتوجة الي تدويره بدل من الطرق الغير صـــحيحة والتي تفقدهم الكثير من العوائد

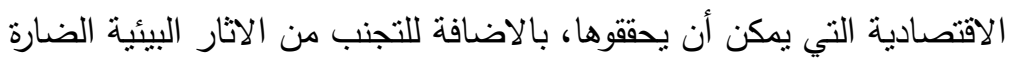




\begin{tabular}{|c|c|c|c|}
\hline \multicolumn{3}{|c|}{ خصائص المزارعين } & \multirow{2}{*}{ الخصائص الشخصية } \\
\hline$\%$ & العدد & الفئات & \\
\hline דו & VY & أقل من Or سنة & \multirow{3}{*}{ 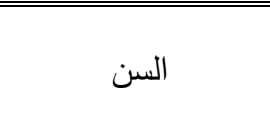 } \\
\hline$\varepsilon$ & $\wedge$. & من ب o - 70 سنة & \\
\hline$r \leq$ & $\Sigma \wedge$ & من 07 فأكثر & \\
\hline $1 \ldots$ & r.. & متزوج ويعول & الحالة الاجتماعية \\
\hline YY & $\varepsilon \varepsilon$ & أميون & \multirow{4}{*}{ الحالة التعليمية } \\
\hline 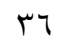 & VY & يقرأ ويكتب & \\
\hline$r$. & 7. & مؤهلات منوسطة & \\
\hline ir & $r \leq$ & مؤهلات عليا & \\
\hline or & $1 \cdot \varepsilon$ & مزارع فقط & \multirow{2}{*}{ المهن غير الزراعية } \\
\hline$\varepsilon \wedge$ & 97 & مزارع + مهنة أخرى & \\
\hline 1. & $r$. & أققل من ب فدان & \multirow{3}{*}{ الحيازة الزراعية } \\
\hline $1 \varepsilon$ & $7 \wedge$ & من r- r فدان & \\
\hline 07 & 114 & من r فأكثر & \\
\hline
\end{tabular}

المصدر: استمارة الاستبيان

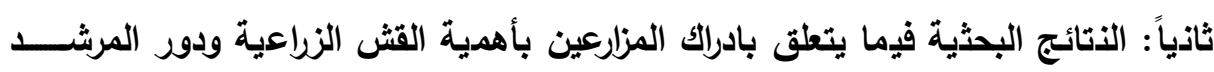
الزراعى وجهاز البيئة:

- يتبين أن جميع أفراد عينة الدراسة لديهم معرفة بالقش الزراعية

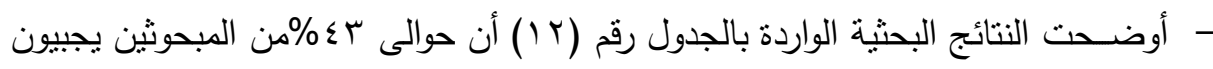

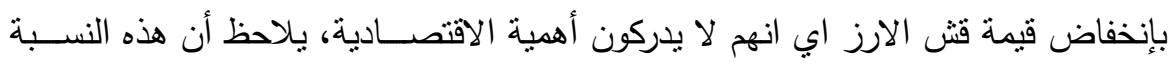

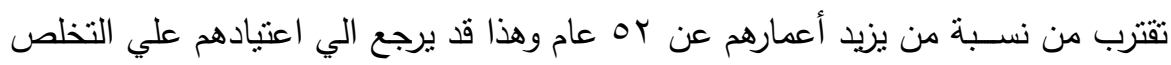

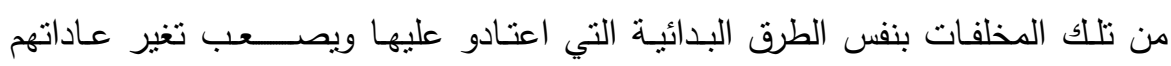

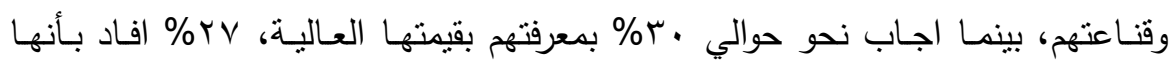
متوسطه القيمة - كما أوضحت النتائج البحثية أن Vج\% من الزراع المبحوثين أشاروا الى عدم نواجد المرشد

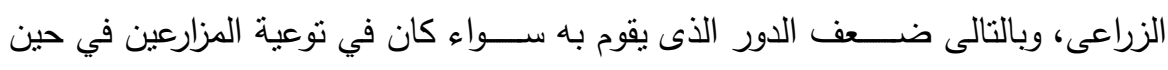

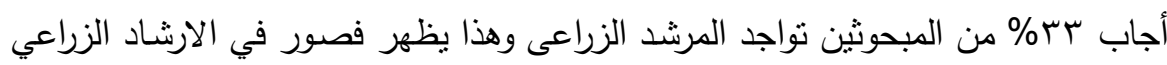
الذي يجب أن يكون له دور في التوعيه. 
- كما أوضحت النتائج البحثية الى أن TV\% فقط من المزارعين أنثاروا الى دور جهار شئون

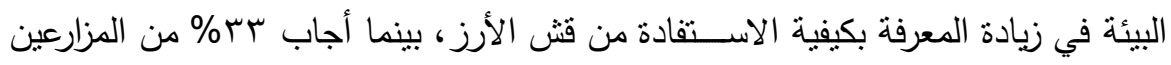

بعدم وضوح دور جهار شئون البيئة في زيادة المعرفة بكيفية الاستفادة من قش الأرز .

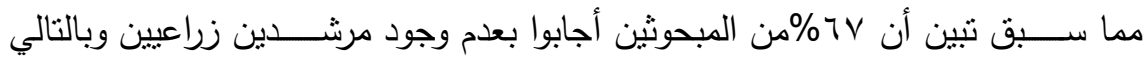

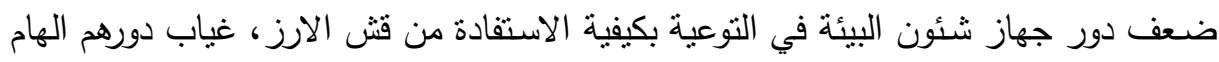

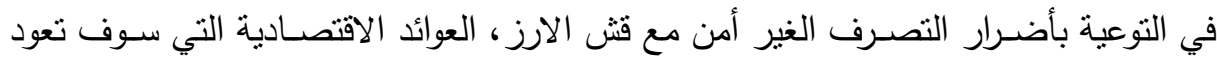
علي المزارعين في حالة تدويرهم لمخلفات قش الأرز ، الطرق المختلفة لتدويره.

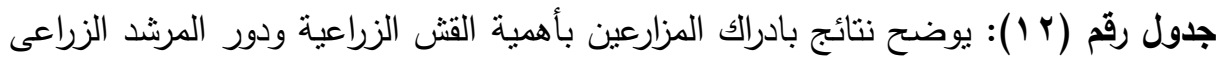
وجهاز البيئة

\begin{tabular}{|c|c|c|c|}
\hline \multicolumn{3}{|c|}{ خصائص المزارعين } & \multirow{2}{*}{ الخصائص الثخصية } \\
\hline$\%$ & العدد & الفئات & \\
\hline $1 \ldots$ & r.. & نع لَ & هل تعرف ما هي المخلفات \\
\hline r. & 7. & عالية & \multirow{3}{*}{ ق قيمة القش } \\
\hline rV & $0 \leqslant$ & متوسطة & \\
\hline$\varepsilon r$ & 人т & منخفضة & \\
\hline ru & 77 & نعم & \multirow{2}{*}{ هل يوجد مرشد زراعي } \\
\hline TV & $1 \pi \varepsilon$ & $y$ & \\
\hline $1 \cdots$ & $\begin{array}{c}r_{\ldots} \\
.\end{array}$ & نع & هل تتشر ان هنالك اضرار تتتج من حرق القش \\
\hline TV & $\pi \varepsilon$ & نعم & هل لجهاز شئون البيئة دور في معرفناك بكيفية \\
\hline r & 79 & $\gamma$ & الاستفادة من قش آلآرز \\
\hline
\end{tabular}

المصدر: استمارة الاسنتيان.

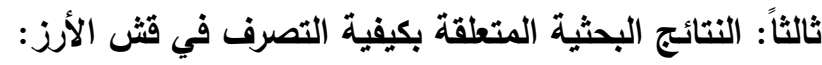
يبين الجدول رقم (ب ا ) كيفية تصرف المحبوثين في قش الأرز بعينة الدراسة ، واسباب اختيار طرق اخرى غير التدوير · مان. - يتبين من الجدول أن حوالي بـ بـ من المبحوثين يحرقون قش الارز في الحقل، حوالي

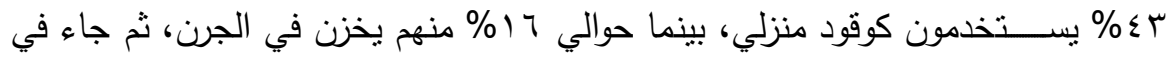

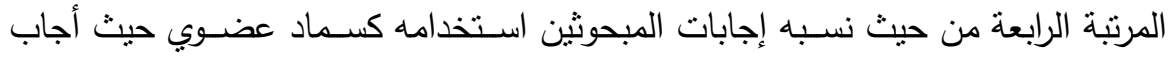


بذلك حوالي ع ا \% من المبحوثين، يليه في ذلك استخدامة في تغذية الحيوانات مباشرة ، أو

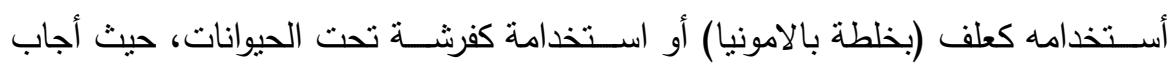

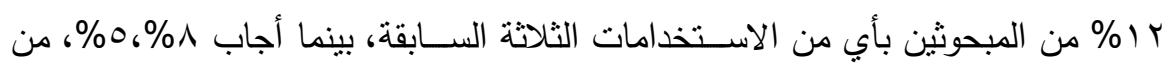
المبحوثين علي الترتيب بووضعة فوق الأسطح، او نركه علي رأس الحقل.

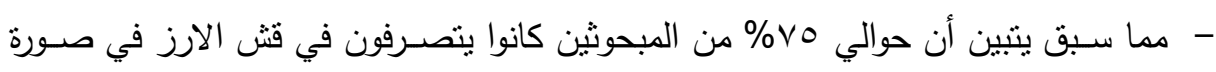

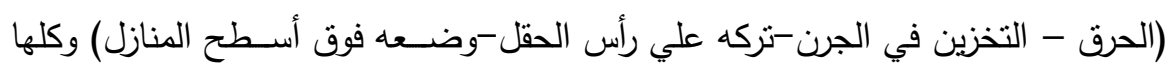

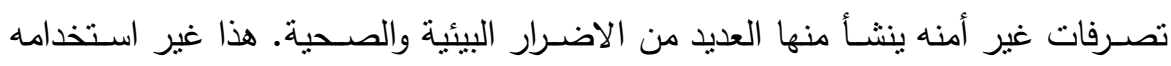

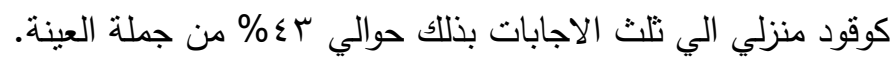

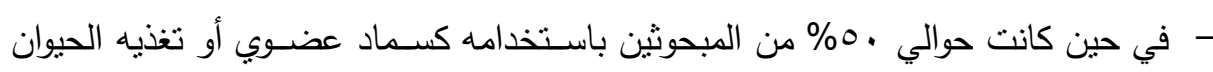
وهذا تصرف غير ضاره بالبيئة وذات عائد اقتصادي.

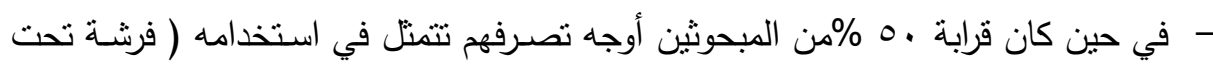

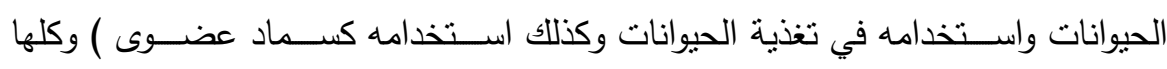
تصرفات جيدة وذات عائد اقتصادي وغير ضـارة بالبيئة، ومن الملاحظ ان هناك مجموعة

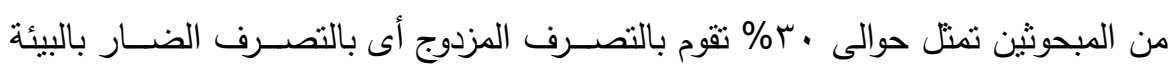

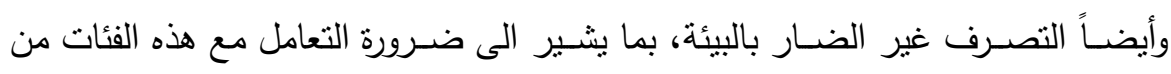
المزارعين بالبرامج الارشادية والتوعوية المناسبة.

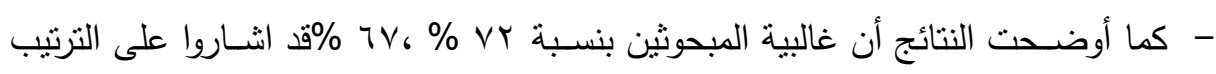

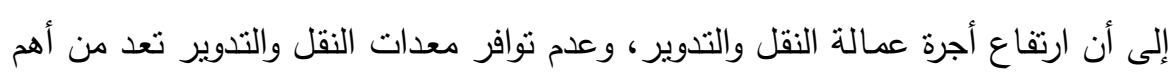

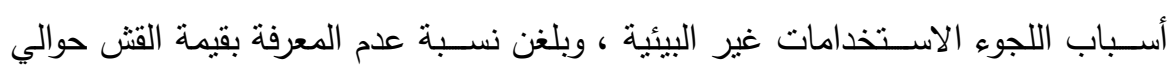

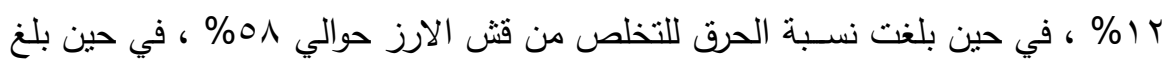

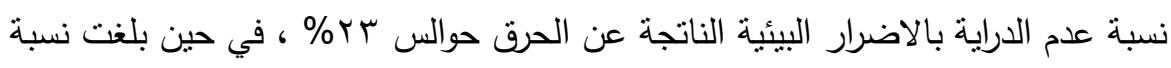

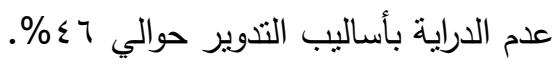


جدول رقم (r 1): الننائج البحثية المتعلقة بكيفية التصرف في قش الأرز وترتيبها وفقاً لأهميتها النسبية

\begin{tabular}{|c|c|c|c|c|}
\hline الترتيب & $\%$ & 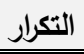 & 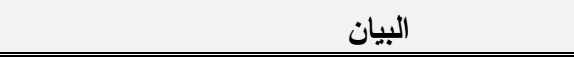 & \\
\hline 1 & 46 & 92 & الحرق في الحقل & \multirow{10}{*}{ أوجها } \\
\hline 2 & 43 & 86 & استخدامه كوقود منزلى & \\
\hline 3 & 16 & 32 & التخزين في الجرن & \\
\hline 4 & 14 & 28 & استخدامه كسماد عضوى & \\
\hline 5 & 12 & 24 & فرشة تحت الحيوانات & \\
\hline 6 & 12 & 24 & استخدامه في تغذية الحيوانات & \\
\hline 7 & 12 & 24 & استخدامه كعلف (خلطه بالامونيا) & \\
\hline 8 & 8 & 16 & وضعه فوق سطح المنزل & \\
\hline 9 & 5 & 10 & تركه على رأس الحقل & \\
\hline 10 & 0 & 0 & استخدامه أخرى & \\
\hline 1 & 57 & 114 & عدم تلوث الهواء & \multirow{4}{*}{ الاستخدام } \\
\hline 2 & 48 & 96 & تتظيف القرية من المخلفات & \\
\hline 3 & 25 & 50 & توفير الاعلاف & \\
\hline 4 & 25 & 50 & توفير الاسمدة & \\
\hline 1 & 72 & 144 & ارتفاع أجرة عمالة النقل والتدوير & \multirow{6}{*}{ اللجوء السباب إلى البئيدامات } \\
\hline 2 & 67 & 134 & عدم توافر المعدات للنقل والتذوير & \\
\hline 3 & 58 & 116 & الحرق اسرع كأسلوب للتخلص من قش الأرز & \\
\hline 4 & 46 & 92 & عدم الدراية بأساليب التدوير & \\
\hline 5 & 23 & 46 & عدم الدراية بكافة الاضرار البيئية الناتجة عن الحرق & \\
\hline 6 & 12 & 24 & عدم المعرفة بالقيمة الاقتصادية لقش الارز & \\
\hline
\end{tabular}

المصدر : استمارة الاسنيان.

رابعاً: النتائج البحثية المتعلقة بالمثــــانلات التي تواجه المبحوثين في تدوير قثل الأرز

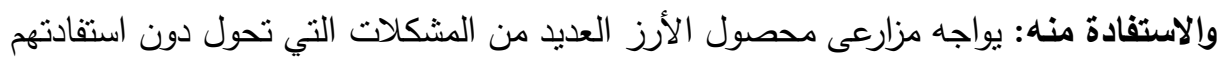

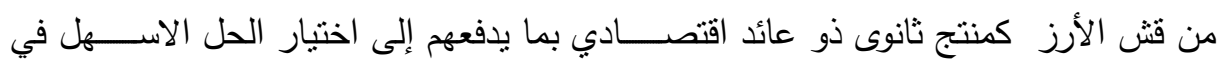


التخلص منه بطرق قد تكون ذات ضـرر على البيئة ، وســوف يتم التعرف فيما يلى على أهم هذه المشكلات ، ومقترحات حلها من وجهة نظر المبحوثين.

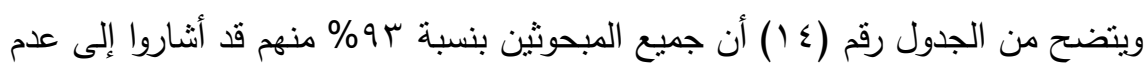

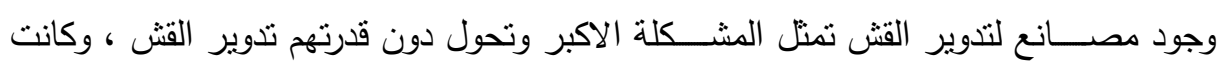

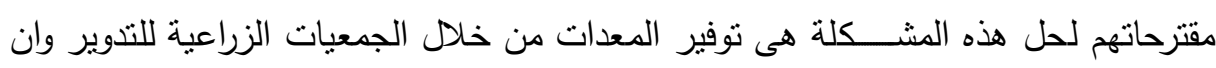

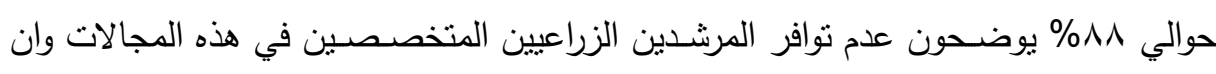

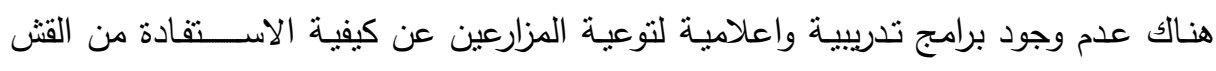

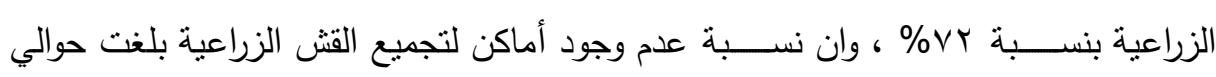

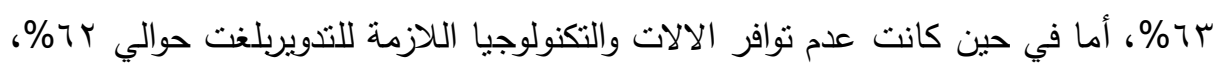

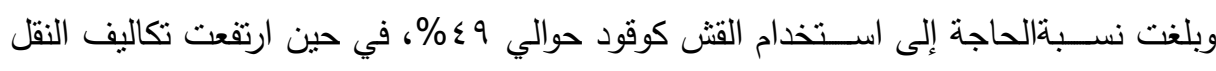

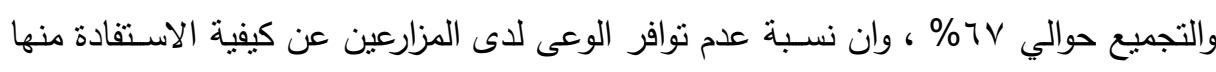

$$
\text { بلغت نحو }
$$

جلول رقم ( ( ) ): المشكلات التي تواجه المزارعين في حالة الرغبة في تدوير قش الارز وترتيبها وفقاً لأهميتها النسبية

\begin{tabular}{|c|c|c|c|}
\hline الترتيب & $\%$ & التكرارات & المشكلات \\
\hline 1 & 94 & 114 & عدم وجود مصانع لندوير المخلفات \\
\hline $\bar{r}$ & 11 & $1 V 7$ & المجام تواتر المرثـــــين الزراعيين المتخصـــــــين في هذه \\
\hline $\bar{r}$ & VY & $1 \leqslant \varepsilon$ & الاستفادة من القش تدريبية واعلامية لتية لتوعية المزارعين عن كيفية \\
\hline$\varepsilon$ & $7 V$ & $1 \pi \varepsilon$ & ارتفاع تكاليف النقل والتجميع \\
\hline o & 77 & ITr & عدم توافر الوعى لدى المزارعين عن كيفية الاستفادة منها \\
\hline 7 & $7 \pi$ & 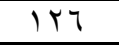 & عدم وجود أماكن لتجميع القش الزراعية \\
\hline $\mathrm{v}$ & 74 & 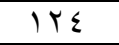 & عدم توافر الالات والتكنولوجيا اللازمة للتنوير \\
\hline$\Lambda$ & $\sum 9$ & 91 & الحاجة إلى استخدام القش كوقود \\
\hline
\end{tabular}


ويتضـح من الجدول رقم (10) مقترحات المزارعين لمواجه مشكلات الاسـتفادة من القش

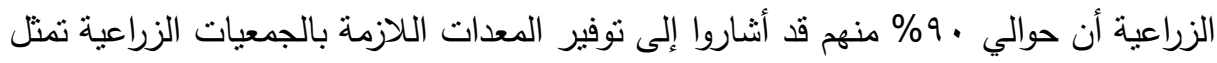

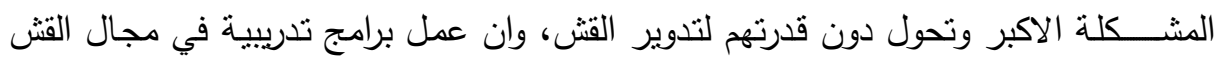

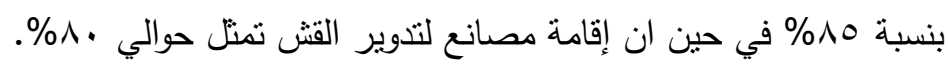

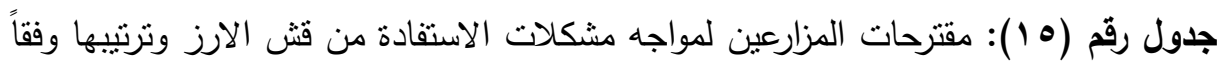
لأهميتها النسبية

\begin{tabular}{|c|c|c|c|}
\hline الترتيب التب & $\%$ & التكرارات & المقترحات \\
\hline 1 & 9. & 11. & توفير المعدات اللزمة بالجمعيات الزراعية \\
\hline r & 10 & iv. & عمل برامج تدريبية في مجال المخلفات \\
\hline r & $\wedge$. & 17. & اقامة مصانع لتدوير القش \\
\hline
\end{tabular}
المصدر: استمارة الاستبيان. خامساً: المشكلات التي تتعلق بالادراك بالاضرار الناتجة عن عن الاستخدام غيى الصـيح لامخلفات

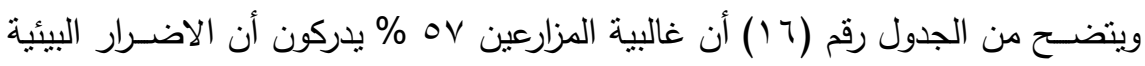
الناتجة عن الاستخدام غير الصحيح للمخلفات الزراعية تؤدى إلى تلوث الهواء.

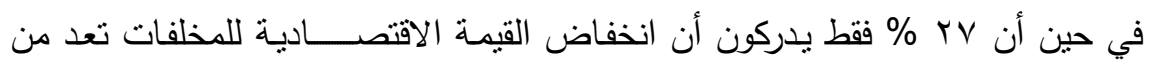

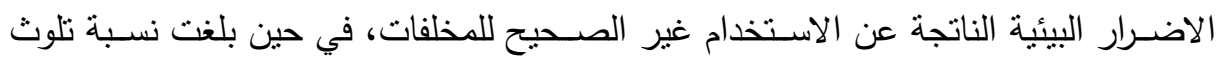

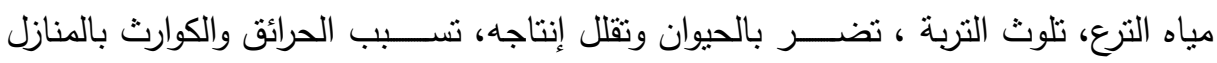

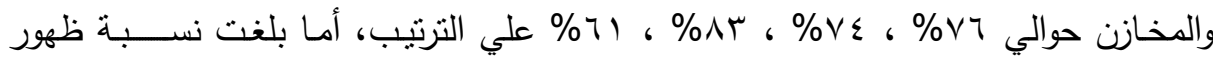

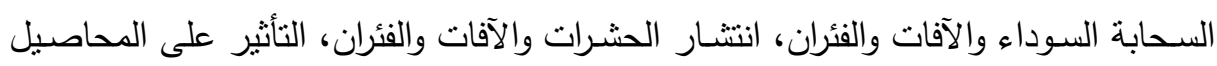

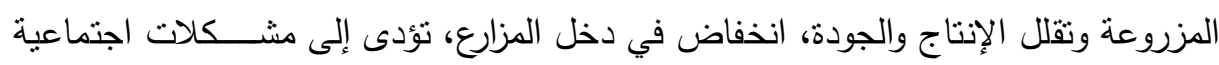
(خلافات مع الجيران)، نشوية مناظر البيئة ومناظر الثوارع • 


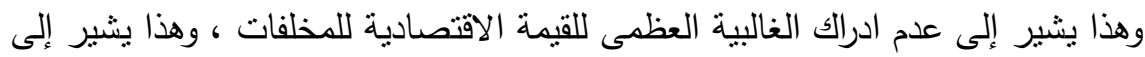

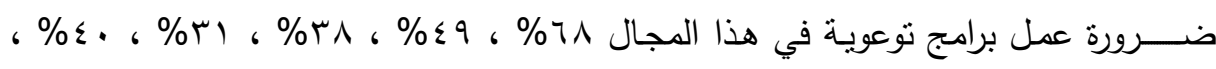

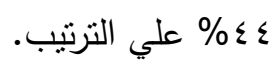

جدول رقم (7 (1): ادراك المزارعين بالأضرار الناتجة عن الاستخدام غير الصحيح لقش الارز وترتيبها وفقاً لأهميتها النسبية

\begin{tabular}{|c|c|c|c|}
\hline الترتيب & $\%$ & 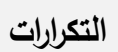 & الأضرار البيئية والاقتصادية \\
\hline 1 & 83 & 177 & تضر بالحيوان وتقلل إنتاجه \\
\hline r & 76 & 104 & 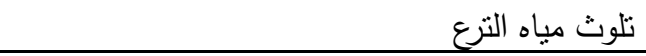 \\
\hline r & 74 & $1 \leq V$ & 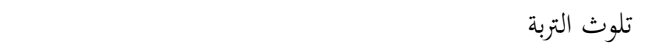 \\
\hline$\varepsilon$ & 68 & 1 ro & تسبب ظهور السحابة السوداء والآفات والفئران \\
\hline 0 & 61 & Irt & نسبب الحرائق والكوارث بالمنازل والمخازن \\
\hline 7 & 57 & $11 \leq$ & تلوث الهواء \\
\hline $\mathrm{v}$ & 49 & 91 & تعمل على انتشار الحشرات والآفات والفئران \\
\hline$\wedge$ & 44 & $\wedge \wedge$ & تشوية مناظر البيئة ومناظر الثوارع \\
\hline 9 & 38 & $\mathrm{VT}$ & تؤثز على المحاصيل المزروعة وتقلل الإنتاج والجودة \\
\hline 1. & 31 & $\pi$ & انخفاض في دخل المزارع \\
\hline 11 & 27 & $0 \leqslant$ & انخفاض القيمة الاقتصادية للمخلفات \\
\hline ir & 20 & $\varepsilon$. & تؤدى إلى مشكلات اجتماعية (خلافات مع الجيران) \\
\hline
\end{tabular}

المصدر: استمارة الاستبيان.

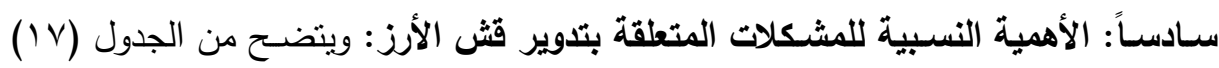

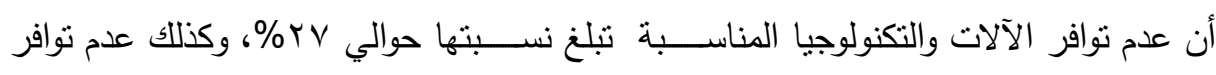

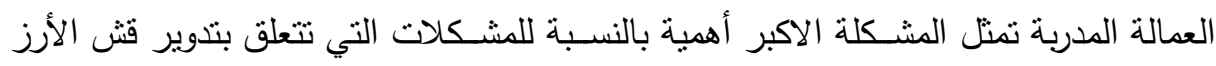

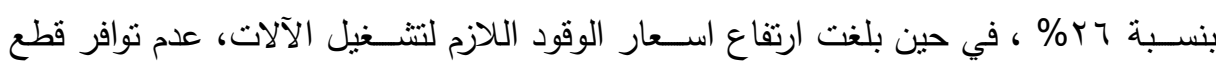

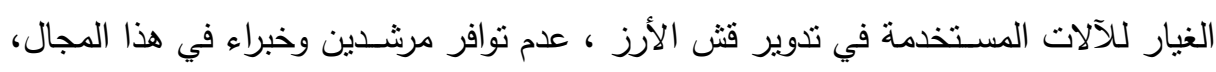

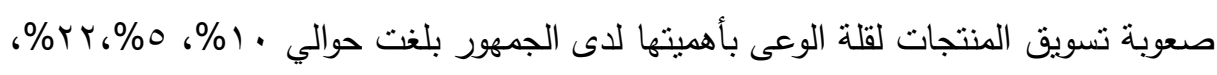
.\%). 
جدول رقم ( V ): ترتيب المشكلات التي تتعلق بتدوير قش الأرز وترتيبها وفقاً لأهميتها النسبية

\begin{tabular}{|c|c|c|c|}
\hline 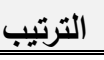 & $\%$ & 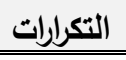 & المشكلات \\
\hline 1 & rV & $0 \leq$ & عدم توافر الآلات والتكنولوجيا المناسبة \\
\hline r & rч & or & عدم نوافر العمالة المدربة \\
\hline$r$ & rt & $\varepsilon \varepsilon$ & عدم توافز مرشدين وخبراء في هذا المجال \\
\hline$\varepsilon$ & 1. & r. & ارتفاع اسعار الوقود اللازم لتشغيل الآلات \\
\hline 0 & 1. & $r$. & صــــوبة تنـــــيق المنتجات لقلة الوعى بأهميتها لدى \\
\hline 1 & 0 & 1. & عدم توافر قطع الغبار للآلات المســتخدمة في تدوير قش \\
\hline $\mathrm{V}$ & $1 \ldots$ & r.. & 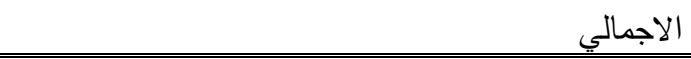 \\
\hline
\end{tabular}

المصدر : استمارة الاستيبان.

العائد الاثتصادي من تدوير قش الأرز: تم تقسيم عينة الدراسة وفقا للمساحة المزروعة بالأرز

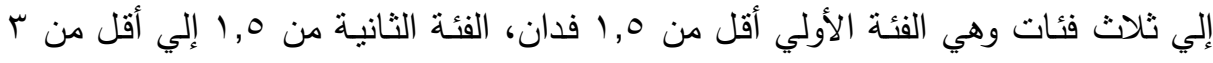

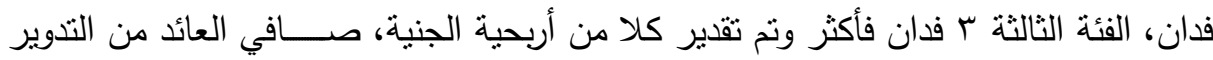

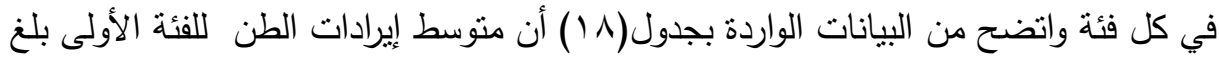

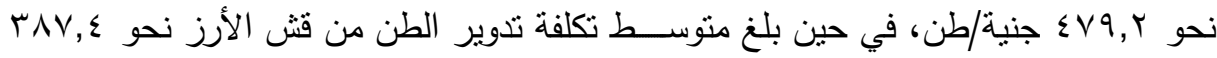

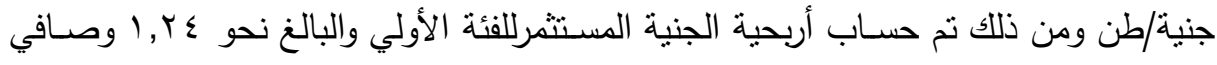
العائد لهذه الفئة نحو ^, 19 جنية/طن خلال الموسم المشار إليه.

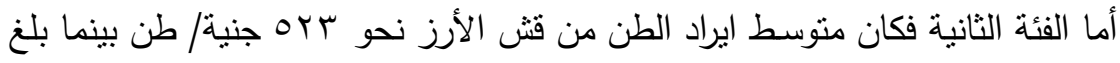

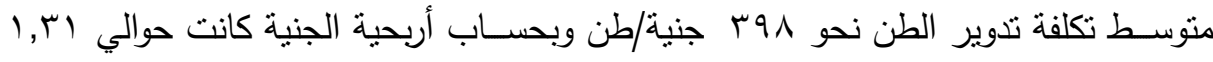
وصافي العائد نحو مبا جنية/طن لهذه لفئة الفئة لذلك الموسم. أما بالنسبة للفئة الثالثة فكان متوسط ايراد الطن من قش الأرز نحو

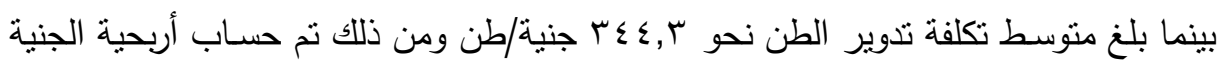

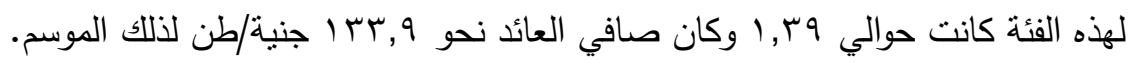


مما سبق يتضح من تدوير قش الأرزتزايد أربحية الجنية، وصافي العائد من التدوير، كما

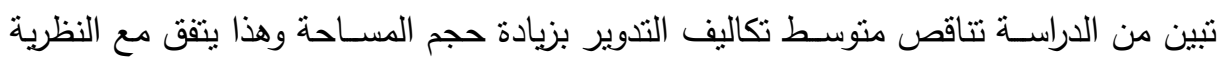
الاقتصادية (وفورات السعة).

جدول (1 1): أربحية الجنية وصافي العائد لناتج تدوير طن قش الأرز في عينة الدراسة

\begin{tabular}{|c|c|c|c|c|}
\hline (جنية/طن) (1) (1) & الجنية (ץية ) & (التكاليف) & (الايراداتط & الفئة \\
\hline 91,1 & $1, r \varepsilon$ & $\Gamma \wedge \gamma, \varepsilon$ & $\varepsilon \vee \vee, r$ & أقل من 0, 1 فدان \\
\hline Ko & $1, r)$ & rqA & OrT & من 1 إن فدان إلى أقل من r \\
\hline $1 \mu r, q$ & $1, r q$ & $r \leqslant \varepsilon, r$ & $\varepsilon \vee \wedge, Y$ & r فدان فأكثر \\
\hline
\end{tabular}

المصدر : جمعت وحسبت من نتائج استمارة استنيان

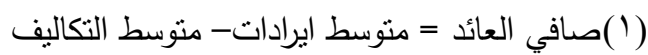
(r)(اربحية الجنية = منوسط ايرادات/ منوسط النكاليف

توضــــح البيانات الواردة بجدول (9 1 ) عائد الجنية من تدوير فش الأرز إلي علف غير

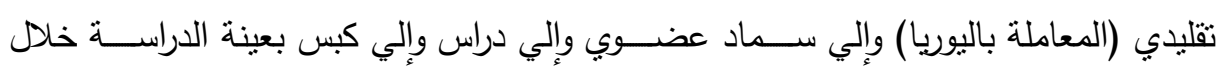

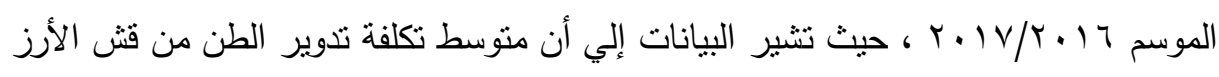

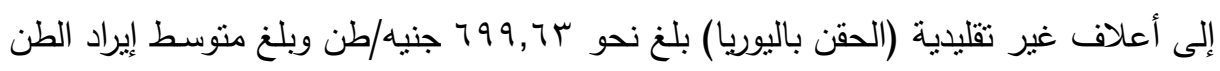

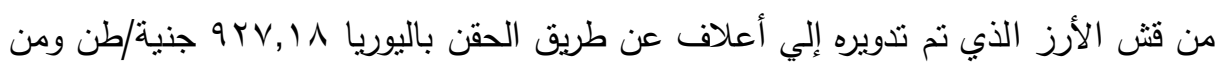

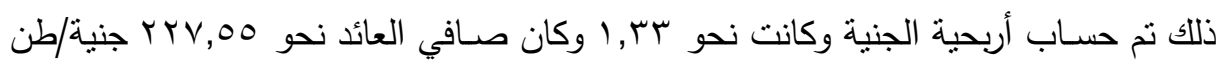

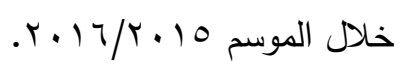

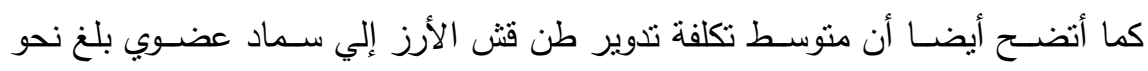

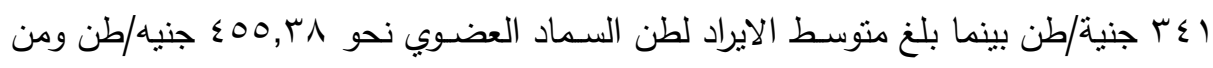

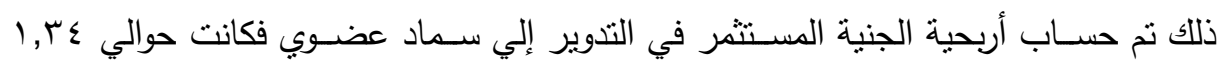

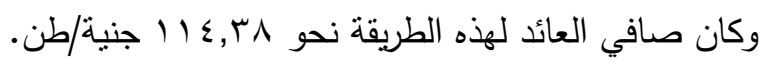

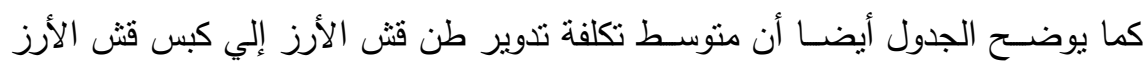

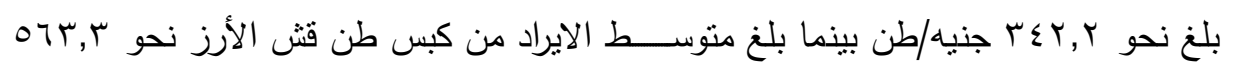


جنيه/طن ومن ذلك تم حساب أربحية الجنية المستثر فكانت حوالي 70 , أوكان صافي العائد

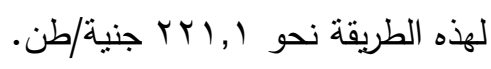

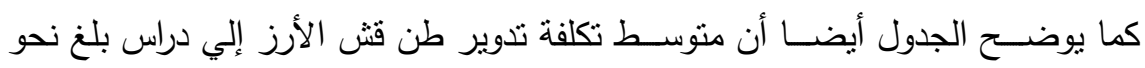

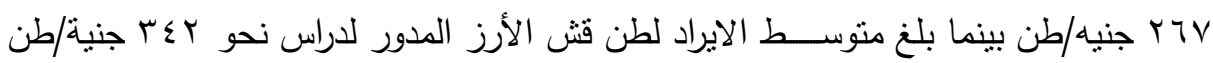

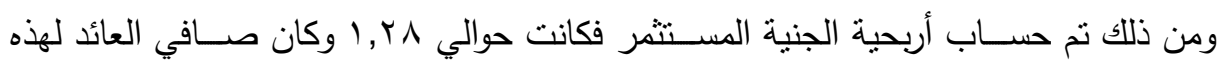

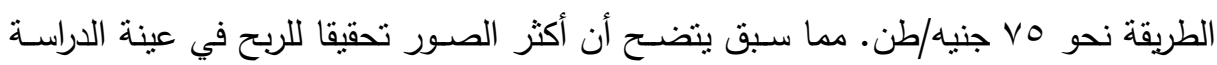
هي تدوير قش الأرز إلي أعلاف (الحقن باليوريا)، ثم الكبس، ثم السماد العضوي، ثم الثم الدراس. جدول (9 (1): أربحية الجنية وصـافي العائد لناتج تدوير طن قش الأرز إلي الصــور المختلفة في عينة الدراسة

\begin{tabular}{|c|c|c|c|c|}
\hline (جنية/طن)(بافي ) & أريحية الجنية & متوسطة التكاليف & متوسطة الايرادات & صورة التدوير \\
\hline KYV,OD & 1, & $799,7 \pi$ & $9 r v, 11$ & حقن يوريا \\
\hline$\| \leqslant, \Gamma \wedge$ & $1, r \varepsilon$ & $r \leqslant 1$ & $\leqslant 00, r \wedge$ & سماد \\
\hline KYI, II & 1,70 & $r \leqslant Y, Y Y$ & KT,TH & كبس \\
\hline vo,.. & $1, Y \wedge$ & KTV & $r \leqslant r$ & دراس \\
\hline
\end{tabular}

المصدر : جمعت وحسبت من نتائج استمارة استنيان .

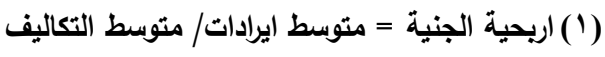

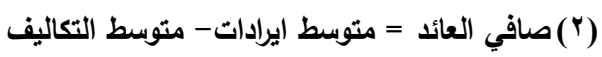

عائد ناتج تدوير قش الأرز علي مستوي محافظة الثـرقية والقيمة المضسافة من عينة الدراسـة عام

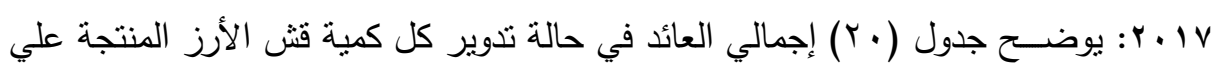

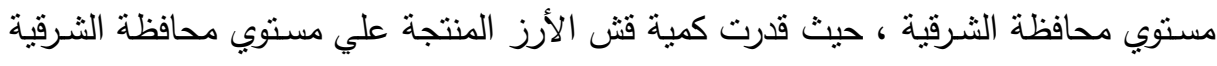

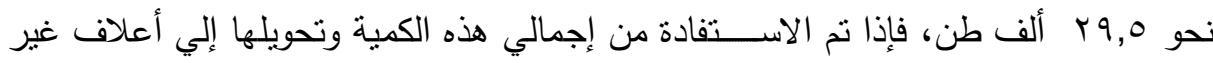

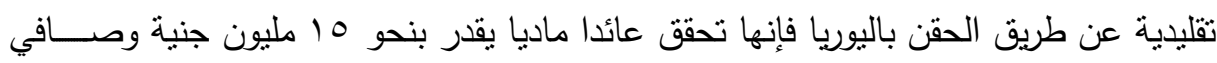

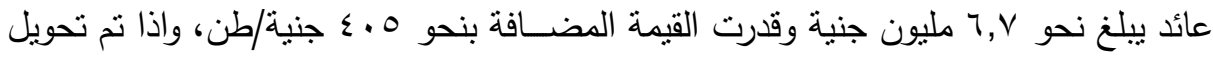

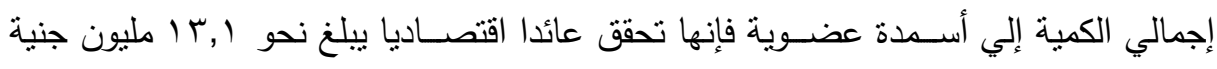


وصـافي عائد يقدر بنحو ع, ـ مليون جنية وبلغت القيمة المضـافة نحو هبr جنية، أما إذا تم

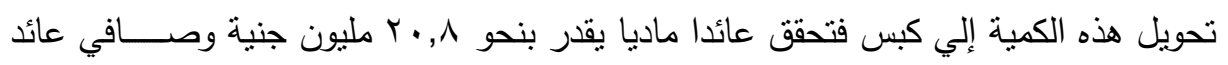

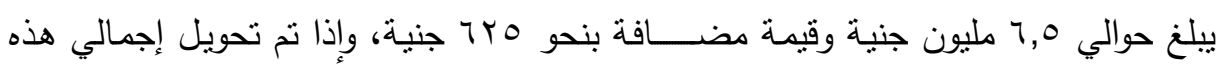

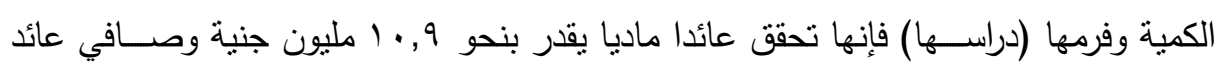

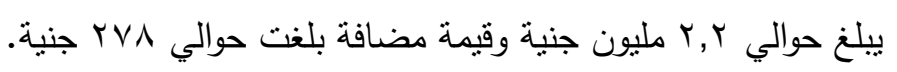

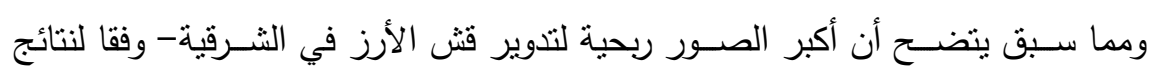

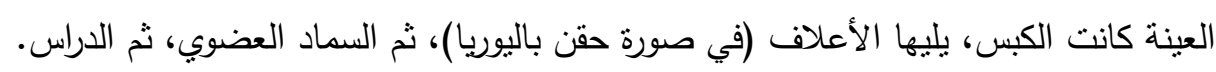

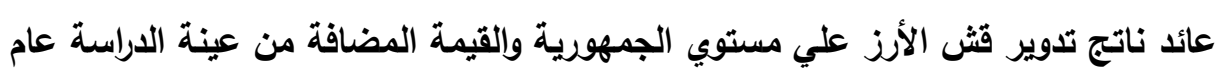

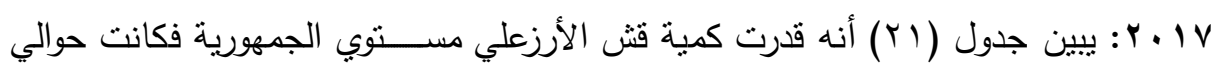

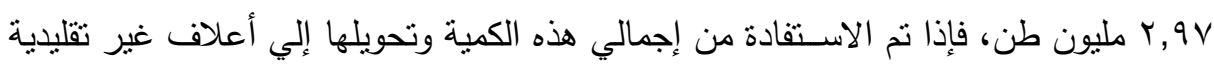

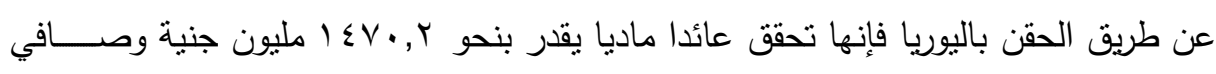

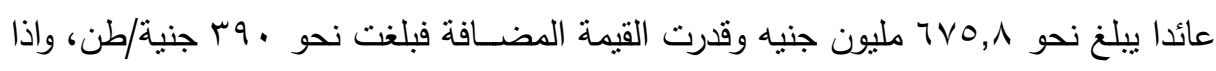

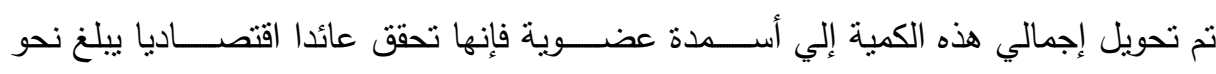

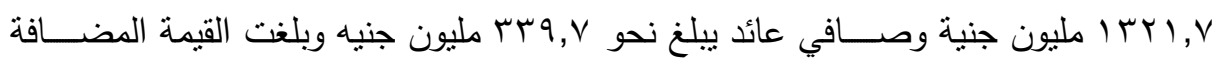

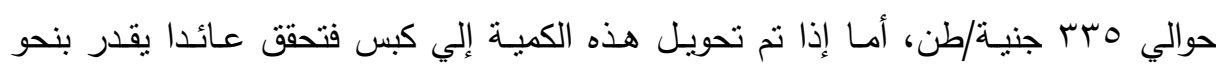

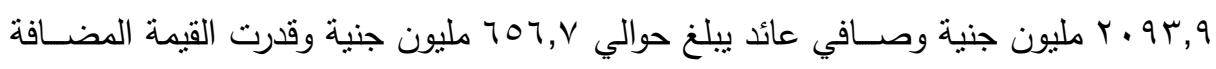

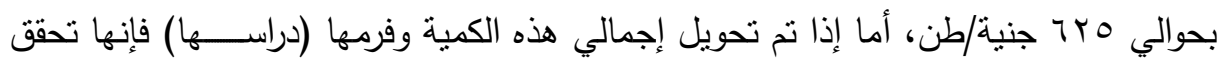

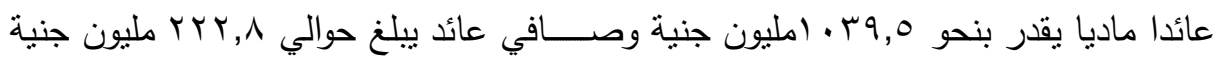
وقيمة مضافة بنحو · •r جنية/طن. 
جلول( • Y): عائد ناتج تدوير قش الأرز على مستوى محافظة الشرقية والقيمة المضافة من

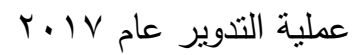

\begin{tabular}{|c|c|c|c|c|c|c|}
\hline القضيةفة القنية) & العائد(ا)م) & الطن (أرجية(جنيه) & (لعليائد (1) & (المتوسطر & (ألفية & صورة التدوير \\
\hline 405.00 & $7, \mathrm{~V}$ & TrV,T & 10, & 01. & $r 9,0$ & أعلاف (حقن \\
\hline 335.00 & $r, \varepsilon$ & $11 \varepsilon, \varepsilon$ & $1 r, 1$ & $\leqslant \leqslant 0$ & $r 9,0$ & سماد عضوى \\
\hline 625.00 & 7,0 & TYI,I & $r \cdot, \Lambda$ & 8.0 & $r q, 0$ & كبس \\
\hline 278.00 & $Y, Y$ & $\mathrm{~V} 0,$. & $1 \cdot, 9$ & $r 4 \Lambda$ & $r q, 0$ & دراس \\
\hline
\end{tabular}

المصدر: مديرية الزراعة بالثرقية- جمعت وحسبت من نتائج استمارة اسنتيان

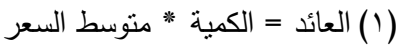

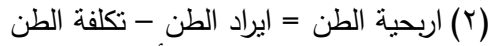

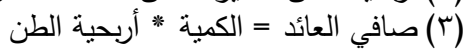
(أ) القيمة المضافة = سعر الطن بعد التذوير - سعر طن قش الأرز

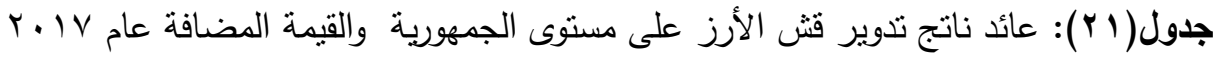

\begin{tabular}{|c|c|c|c|c|c|c|}
\hline المضيفة & صافي & أرينية & العائد(مليون) & متوسط سعر & "(مليون & صورة التدوير \\
\hline 390.00 & $T \vee 0, \Lambda$ & $r Y V, T$ & $1 \leqslant V \cdot, r$ & $\leqslant 90$ & r, $9 V$ & أعلاف (حقن \\
\hline 335.00 & $r r q, V$ & $11 \varepsilon, \varepsilon$ & $\mid r Y, V$ & $\varepsilon \leqslant 0$ & $r, 9 V$ & سماد عضوى \\
\hline 625.00 & $707, \mathrm{~V}$ & $r Y, 1$ & $r .9 r, 9$ & $V .0$ & $r, 9 V$ & كبس \\
\hline 260.00 & YYY,A & $\mathrm{V} 0, \cdot$ & $1 . r 9,0$ & ro. & r, $9 \mathrm{~V}$ & دراس \\
\hline
\end{tabular}

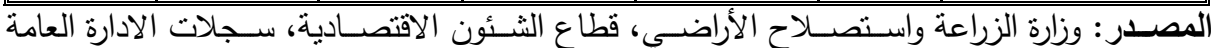

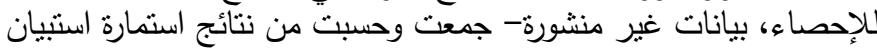

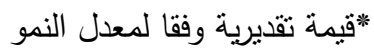

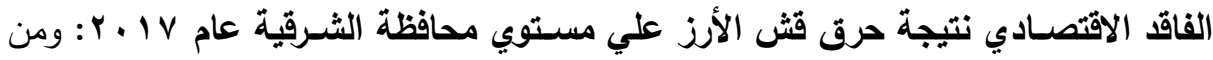
جدول (Yr) يمكن تقدير إجمالي العائد المفقود نتيجة حرق قش الأرز بالمحافظة، حيث قدرت

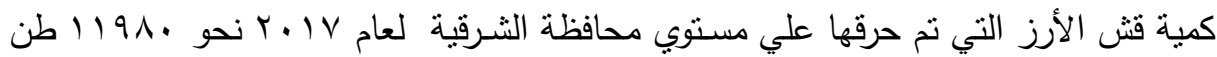
فإذا نم الاســـفادة من هذه الكمية وتدويرها إلي أعلاف غير تقليدية (حقن يوريا) يتحقق عائدا 
اقتصاديا يقدر بنحو /,7, مليون جنية وهذا يمثل عائدا مفقودا نتيجة عدم الاستخدام الصحيح

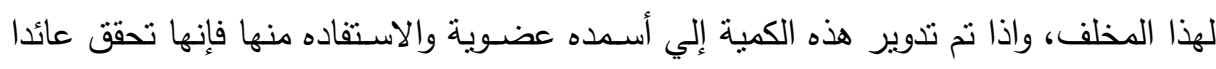

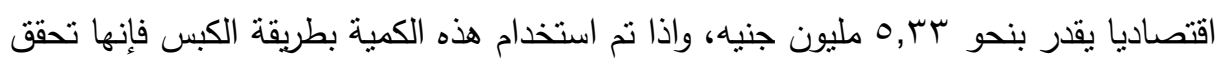

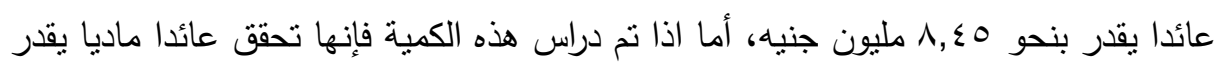
بنحو اء اء مليون جنية ويمنل هذا فاقدا لم ينم الاستفاده به.

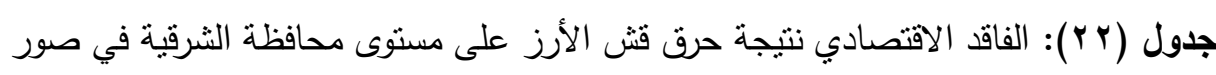

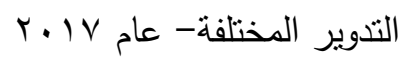

\begin{tabular}{|c|c|c|c|}
\hline 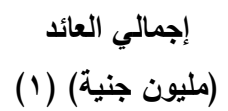 & سعر طن & كمية القش المحروق (الفاقد) & البيان \\
\hline 6.11 & 01. & 1191. & أعلاف (حقن باليوريا) \\
\hline 5.33 & $\leqslant \leqslant 0$ & 1191. & سماد عضوى \\
\hline 8.45 & v.o & 1191. & كبس \\
\hline 4.41 & גוא & 1191. & دراس \\
\hline
\end{tabular}

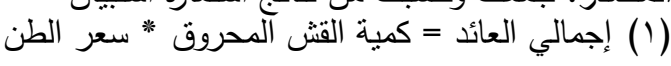

\section{التهوبيايت}

ا ـ إقامة وحدات ومصانع لتدوير القش الزراعية بالمحافظات الأكبر إنتاجاً للمخلفات النباتية مثل محافظات الثرقية، البحيرة والدقهلية.

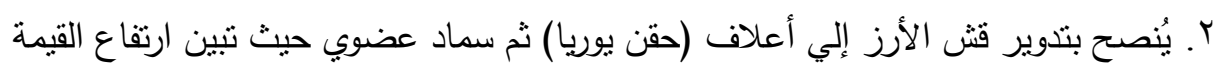

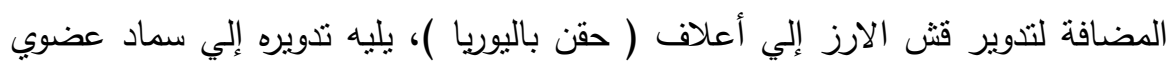

$$
\text { وذلك علي مستوي الجمهورية. }
$$

r. الاهتمام بكبس قش الأرز وذلك لارتفاع القيمة المضافة الناتجة عن عملية الكبس وسهولة

$$
\text { إجراءها واحتياجه لامكانيات أقل بالنسبة للمزارعين. }
$$

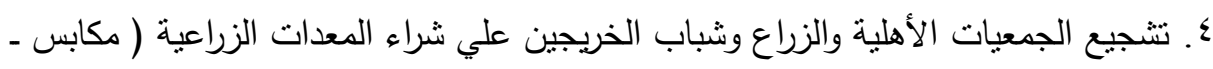

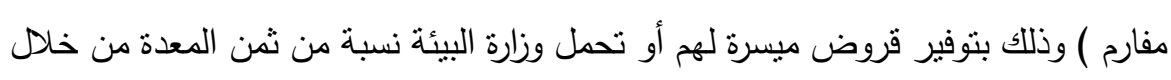




\section{وضع بروتوكولات بين الصندوق الاجتماعي للتتمية أو جهاز تتمية المشروعات لتشجيع الثباب والاستفادة من طاقاتهم.}

\section{المرائ}

احمد، السعيد محمد شعبان: دراسة اقتصادية لامكانية الاستفادة من القش الزراعية،

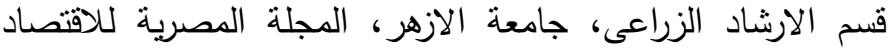

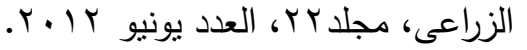

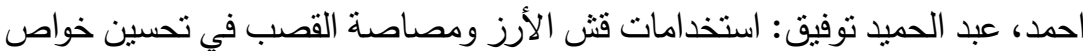

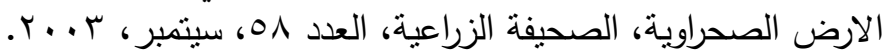

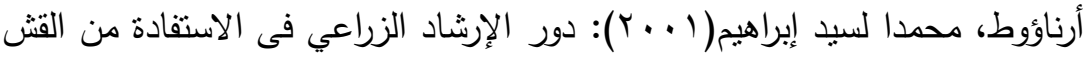

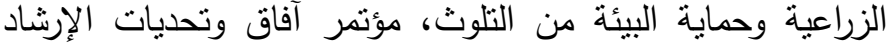

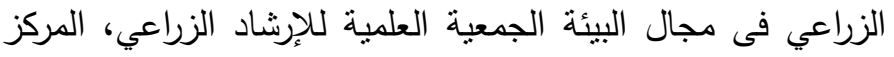

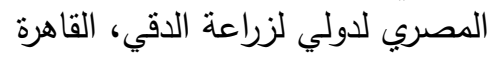

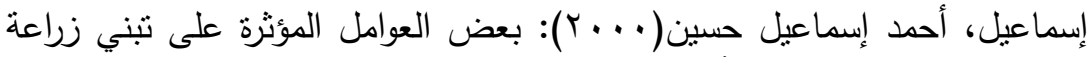

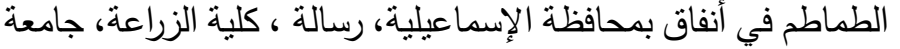

$$
\text { عين شمس في الف }
$$

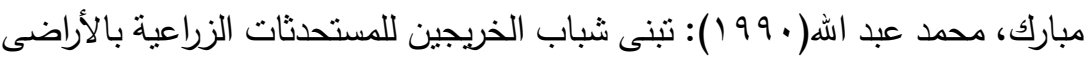

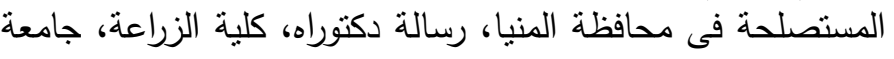




\title{
AN ANALYTICAL STUDY FOR RECYCLING RICE STRAW IN SHARKIA GOVERNORATE
}

\author{
Siham Abdel Rahman ${ }^{(1)}$; Fatma A. Fahmy ${ }^{(2)}$; \\ Mohamed E. Elnanna ${ }^{(2)}$ and Seham A.Abdel Hamid ${ }^{(1)}$
}

1) Post Gard. Institute of Environmental Studies and Research, Ain Shams University 2) Faculty of Agriculture, Ain Shams University

\begin{abstract}
Due to limited agricultural production and the continuous increase in the population of Egypt, the state tends to benefit from agricultural hay, which are products harvesting field crops and agricultural products as well as animal straw. In addition to the disposal of agricultural straw, which may be the cause of the transfer of agricultural pests and pollution of the environment as a result of decomposition leading to the transmission of diseases and the problem was that dealing with agricultural straw including rice straw is an environmental challenge and economic disposal of these large quantities of rice straw by burning This leads to an environmental catastrophe caused by air pollution and the formation of the so-called black cloud and its impact on public health, especially since about $95 \%$ of the total population is concentrated rice straw production in the densely-populated Delta governorates, and all respondents $(93 \%)$ indicated that there are no factories Rotate straws represent The biggest problem is preventing them from recycling hay. Their proposals to solve this problem are to provide equipment through agricultural recycling associations and about $88 \%$ show a lack of agricultural extension specialists Specialists in these are free and there is a lack of training and information programs to educate farmers on how to utilize agricultural hay by $72 \%$, and the lack of places to collect hay Agricultural has reached about $63 \%$, while the lack of machinery and recycling technology was about $62 \%$, the need to use straw as fuel about $49 \%$, while transportation and assembly costs increased by about $67 \%$, and lack of awareness among farmers about how to benefit from it about $66 \%$.
\end{abstract}

Keywords: rice straw, net yield, environmental and economic impacts

$$
\text { المجلد الثامن والأربعون، الجزء الثالث، ديسمبر } 9 \text { 1 ـ }
$$

